\title{
Integrated Pest Management of Coffee Berry Borer: Strategies from Latin America that Could Be Useful for Coffee Farmers in Hawaii
}

\author{
Luis F. Aristizábal ${ }^{1, *}$, Alex E. Bustillo ${ }^{2}$ and Steven P. Arthurs ${ }^{1}$ \\ 1 Mid-Florida Research \& Education Center, University of Florida/IFAS, 2725 Binion Rd, Apopka, FL 32703, \\ USA; spa@ufl.edu \\ 2 Centro de Investigación en Palma de Aceite (Cenipalma), Calle 20 A No. 43 A-50, Pisos 2 y 4, Bogotá D.C., \\ Colombia; alexe.bustillo@gmail.com \\ * Correspondence: larist@ufl.edu or laristizabal721@gmail.com
}

Academic Editors: Michael J. Stout, Jeff Davis, Rodrigo Diaz and Julien M. Beuzelin Received: 30 November 2015; Accepted: 25 January 2016; Published: 3 February 2016

\begin{abstract}
The coffee berry borer (CBB), Hypothenemus hampei Ferrari (Coleoptera: Curculionidae: Scolytinae) is the primary arthropod pest of coffee plantations worldwide. Since its detection in Hawaii (September 2010), coffee growers are facing financial losses due to reduced quality of coffee yields. Several control strategies that include cultural practices, biological control agents (parasitoids), chemical and microbial insecticides (entomopathogenic fungi), and a range of post-harvest sanitation practices have been conducted to manage $\mathrm{CBB}$ around the world. In addition, sampling methods including the use of alcohol based traps for monitoring CBB populations have been implemented in some coffee producing countries in Latin America. It is currently unclear which combination of CBB control strategies is optimal under economical, environmental, and sociocultural conditions of Hawaii. This review discusses components of an integrated pest management program for CBB. We focus on practical approaches to provide guidance to coffee farmers in Hawaii. Experiences of integrated pest management (IPM) of CBB learned from Latin America over the past 25 years may be relevant for establishing strategies of control that may fit under Hawaiian coffee farmers' conditions.
\end{abstract}

Keywords: Hypothenemus hampei; cultural practices; biological control; monitoring; post-harvest; Beauveria bassiana; Cephalonomia stephanoderis; Prorops nasuta; Phymastichus coffea; Cathartus quadricollis

\section{Introduction}

Native to Africa, two species of coffee, Coffea arabica L. and C. canephora Pierre ex A. Froehner (Gentianales: Rubiaceae) are produced on over 10 million ha in 80 countries located in tropical and subtropical regions [1-3]. According to ICO [4], coffee production worldwide has increased by over $50 \%$ in the past 25 years, from 93 million bags $(60 \mathrm{~kg})$ in 1990 to 143 million bags in 2014/15. The total value of the coffee industry during 2012 was estimated at US \$173 billion [4]. In Hawaii the area planted under coffee was estimated at 3440 ha with farm revenue US $\$ 50.3$ million in 2014/15 [5]. Since the coffee berry borer (CBB), Hypothenemus hampei Ferrari (Coleoptera: Curculionidae: Scolytinae), the most economically important insect pest in coffee plantations [3,6-9], was reported in Hawaii in September 2010 [10], coffee farmers from the islands have faced losses in yields and revenue. A similar situation occurred in Brazil in 1913, in Colombia in 1988 and in other Latin American countries in 1970s, 1980s, and 1990s when the CBB was detected [7,11-14]. Here we summarize lessons learned regarding the integrated pest management (IPM) of CBB from Colombia and Latin America that could be applied to Hawaii and elsewhere. 
Three important topics about the CBB discussed in this review are (1) Biology, ecology, and behavior, which are needed to understand the pest and its management; (2) IPM, including components such as monitoring, cultural control, use of mycopesticides, natural enemies, post-harvest control strategies, and coffee rejuvenation; and (3) Recommendations for coffee growers, Extension workers, and IPM researchers.

\section{Biology, Ecology, and Behavior of CBB}

Establishing an IPM program for CBB requires knowledge about its biology, ecology, and behavior within a specific region. The pest is influenced by crop phenology, especially by periods of coffee blooms, development of berries, and harvesting strategies, (e.g., timing applications of mycopesticides with periods of high CBB flight activity, or cultural control practices with harvesting periods). Several authors have reported comprehensive reviews about the CBB biology and control strategies $[3,7,8,11,15-18]$.

\subsection{General Biology of $C B B$}

All CBB life stages develop inside coffee berries, which make insecticidal control difficult [7-9]. The process of colonization of a healthy berry starts when a mated female initiates the search for new oviposition habitats [9]. Developing green coffee berries with $>120$ days growth post flowering and $>20 \%$ dry weight are preferentially selected $[8,19]$. Younger green berries ( $\geqslant 60$ days old) may also be infested by CBB, but the female has to wait in a penetration channel, until the berries achieve $>20 \%$ dry weight in order to bore a gallery and initiate oviposition $[8,19]$. Early infestation of green berries (60-90 days old) may result in premature drop from trees [7]. Female CBB may attack developing berries until they become mature ( $>224$ days) at harvest time [8]. In general, a hardened developing berry is bored by the female, then irregular tunnels and galleries are excavated in which the female lays her eggs. Females lay between one and three eggs per day over 20 days [15]. After resting, females repeat the oviposition process. According to Barrera [20] a female may lay up to 119 eggs inside a single berry. The CBB develops through six life stages: egg, larva (first and second instar), pre-pupa, pupa, and adult. The life cycle requires at least 25 days and may take $>60$ days depending on temperature and hardness of the berry (endosperm) [8]. The founding female does not leave the berry and remains with her progeny [21]. The mating system is functionally haplo-diploid [22], allowing mating between siblings, which have a female-biased sex ratio of around 10:1. Since developing berries typically require 200-250 days from flowering to harvest, individual berries can support multiple generations of CBB [21]. Jaramillo et al. [23] reported about 4 generations of CBB per year in Tanzania and Colombia, with 3 generations in Kenya, and 2 in Ethiopia. There is a variation of longevity of CBB adults. Female life-span ranges from 81-282 days [15], and average 131 days [24]. Male are shorter lived with longevity reported at 40 days [15] and 52 days [25].

\subsection{Coffee Plant and CBB}

The development of the coffee crop, specifically flowering, development of berries, and harvest time, are related to climate. For example, flowering occurs when rainfall follows a dry period as physiological response of the plant due to water limitation [26,27]. In Colombia, flowering to berry maturation requires 7-9 months depending on temperatures [28]. At $1200 \mathrm{~m}$ above sea level (masl) (average temperature $22^{\circ} \mathrm{C}$ ) berries need 7 months for maturity, at 1400 masl $\left(20.5^{\circ} \mathrm{C}\right) 8$ months, and at 1750 masl $\left(19^{\circ} \mathrm{C}\right) 9$ months [28]. In the central coffee region of Colombia, there are two flowering periods (January and February and August and September) that allow two harvest periods (September until November and March until May) $[26,28]$. There is also some additional flowering that allows developing berries throughout the year. This situation promotes CBB because the beetle finds food and shelter for reproduction all year long, making control more challenging. Coffee berries reach $20 \%$ dry weight between 110 and 140 days after blooms [29,30]. At this point berries become more firm (hardness) allowing infestation and reproduction of CBB. Ruiz [31] reported that developing 
berries $>150$ days old ( $27 \%$ dry weight) are attacked by CBB and oviposition started after $4-5$ days. Baker [8] showed that CBB females prefer older berries $150-240$ days ( $>20 \%$ dry weight) over younger berries $<90$ days old. Higher density plantations and older larger trees provide more habitats for CBB and make control more difficult. Highest $\mathrm{CBB}$ infestations levels were observed on lower branches in contrast to the middle and top of the tree [32]. According to Bustillo [33], records of flowering periods are necessary to predict harvest time, peak harvest, and critical periods of potential attack by CBB.

\subsection{Alternative Host Plants}

CBB adults have been observed in plants other than the genus Coffea [9]. However, the insect life cycle is only known to be completed on coffee species [34]. The presence of CBB adults on other plants may represent transitory shelter until developing coffee berries are available. Plants among the families Fabaceae, Euphorbiaceae, Passifloraceae, Rubiaceae, Arecaceae, Araliaceas, and Anacardiacease were evaluated as potential host plants for CBB in Kona, Hawaii [35]. Some CBB adults were found on "hoale koa" Leucanea leucocephala (Lam.) but were unable to use these plants as hosts [35].

\subsection{Sources and Emergence of $C B B$}

The availability of food and prevailing weather conditions influence the emergence of adult female CBB from infested berries. High relative humidity ( $>90 \%)$ especially after rainfall and increase in temperatures stimulate emergence of the CBB female [8,36,37]. In Colombia the pruning practice known as "zoqueo", which is the rejuvenation of old coffee trees after a decline in production, is a major source of CBB. After they are stumped, the old trees and fallen infested berries release CBB and become a pest reservoir [8,38]. Similarly, feral coffee plantations (abandoned by farmers) in Kona and Pahala regions in Hawaii provide a reservoir of CBB habitat. High infestation of CBB $(81 \%)$ on feral coffee plantations may contribute to the spread of CBB in Hawaii (Table 1, Figure 1A, farm $11^{*}$ in Pahala (Infestation of CBB and degree of penetration of CBB inside berries was conducted according to thirty tree sampling method developed by Bustillo et al. [7] and recommended in Hawaii by Kawabata et al. [39]. The evaluation was conducted by coffee farmers and the first author. See details of methodology on Section 3.1 Sampling CBB Populations)). Ripe and over-ripe berries that are left on the trees after harvest and those that fall on the ground serve as a source of new CBB infestations (Figure 1B,C). During dry conditions, infested fallen berries can contribute a large number of CBB females that are stimulated to emerge by high relative humidity (>90\%) after rainfall [8].

Table 1. Infestation levels of coffee berry borer (CBB), positions of the CBB (AB-CD), infection by B. bassiana (Bb), and mortality of CBB on coffee farms from Pahala, and Kona, Hawaii in September 2015.

\begin{tabular}{|c|c|c|c|c|c|c|}
\hline Farm & CBB & $\mathbf{B b}$ & AB & CD & Mortality & Empty \\
\hline 1 & 66.4 & 64.5 & 32.7 & 16.3 & 39.4 & 11.4 \\
\hline 2 & 49.9 & 42.3 & 18.8 & 15.9 & 44.9 & 20.2 \\
\hline 3 & 26.7 & 16.4 & 23.8 & 6.8 & 30.6 & 38.6 \\
\hline 4 & 23.1 & 61.9 & 18.0 & 19.4 & 47.2 & 15.4 \\
\hline 5 & 14.7 & 23.8 & 24.4 & 13.9 & 15.1 & 46.5 \\
\hline 6 & 10.2 & 19.7 & 9.4 & 26.4 & 30.1 & 33.9 \\
\hline 7 & 4.2 & 27.5 & 36.3 & 26.3 & 8.0 & 19.0 \\
\hline 8 & 3.3 & 11.0 & 64.8 & 17.8 & 1.9 & 18.2 \\
\hline 9 & 3.2 & 9.3 & 39.3 & 45.4 & 6.0 & 9.0 \\
\hline 10 & 2.9 & 22.0 & 10.0 & 8.0 & 26.0 & 56.0 \\
\hline Average \pm SEM & $20.5 \pm 6$ & $29.8 \pm 6$ & $27.8 \pm 5$ & $20.3 \pm 3$ & $24.9 \pm 4$ & $26.8 \pm 4$ \\
\hline $11 *$ & 81.0 & 44.0 & 18.8 & 13.5 & 52.7 & 18.9 \\
\hline $12 * *$ & 0.7 & 9.0 & $\mathrm{n} / \mathrm{a}$ & $\mathrm{n} / \mathrm{a}$ & $\mathrm{n} / \mathrm{a}$ & $\mathrm{n} / \mathrm{a}$ \\
\hline
\end{tabular}

Notes: $\mathrm{CBB}=\%$ Infestation of $\mathrm{CBB}, \mathrm{Bb}=\% \mathrm{CBB}$ infected by $\mathrm{B}$. bassiana, $\mathrm{AB}$ and $\mathrm{CD}=\%$ of $\mathrm{CBB}$ penetration inside berry ( $\mathrm{AB}$ and $\mathrm{CD}$ positions), Mortality $=\%$ Dead CBB female, Empty $=\%$ berries infested but without CBB female. $11^{*}=$ Feral coffee plantation abandoned in Pahala, Hawaii. $12^{* *}=$ New coffee plantation rejuvenate by stump pruning in a block, Greenwell coffee farm in Kona, Hawaii. 


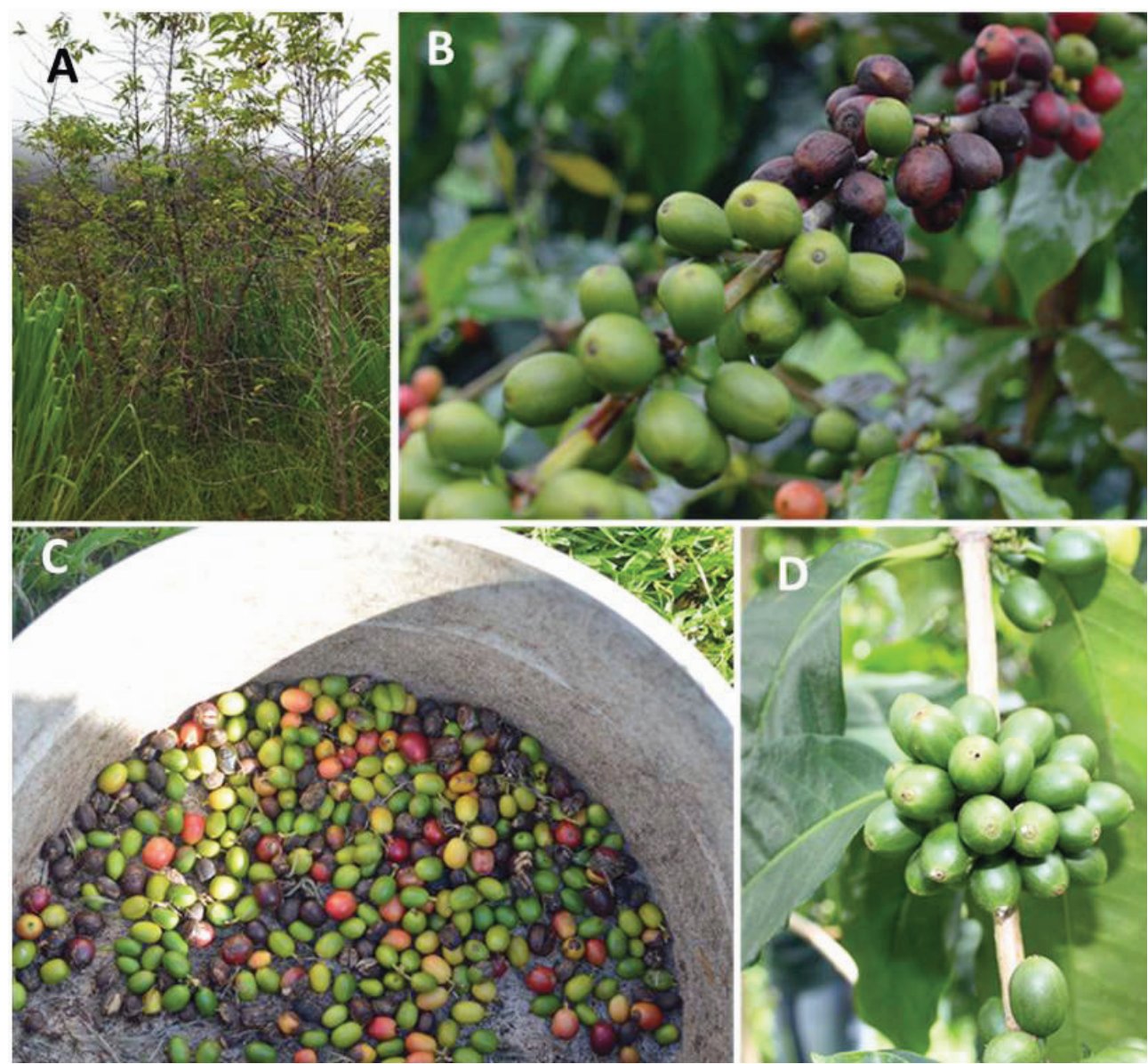

Figure 1. Feral coffee in Hawaii may allow the spread of $\mathrm{CBB},(\mathrm{A})$; over-ripe and raisin berries are high source of CBB (B); berries collected from the ground helps control CBB (C); green berries attacked by CBB (D). Photos taken in Pahala, Hawaii by Libia C. Mahé, and Luis F. Aristizábal.

\subsection{Visual and Olfactory Attractants of $C B B$}

The response of female $\mathrm{CBB}$ to visual cues such as color and movement was reported by several authors [40-43]. The beetles showed preference to black and red in studies conducted with natural and artificially colored berries [40-42,44]. The female CBB has larger eyes and responds to movement while males have rudimentary eyes and poor vision [43,45]. Females are also attracted to kairomones released by developing berries [42,44,46,47]. Coffee berry kairomones are composed of different alcohols [48]. The use of visual and olfactory attractants for CBB is used to improve monitoring through the use of lures. For example, the discovery of $C B B$ females response to methanol and ethanol allowed the application of alcohol based traps for monitoring CBB populations under field conditions in Mexico [49], Central America [50,51], Brazil [52,53], Hawaii [35] and Colombia [54].

\subsection{Flight and Dispersal of $C B B$}

The flight of CBB females was reported by Baker [11]. Laboratory tests showed that CBB can fly unaided for at least $22 \mathrm{~min}$ and $100 \mathrm{~min}$ when tethered. The flight activity peak was observed at 2:00 pm [25] and between 1:30 and 3:30 pm [50]. Males have degenerate wings and cannot fly [9]. According to Decazy [16], most CBB fly short distances, but some disperse long distances searching for berries. Baker [8] reported that CBB from a "zoqueo" coffee plot immigrated to coffee plantation at least $500 \mathrm{~m}$ distant. Long distance dispersal may be achieved via wind, animals, and humans, with international dispersal occurring inadvertently via the coffee trade [34]. 


\subsection{Spatial Distribution of $C B B$}

Initial infestations of $C B B$ in coffee plantations assume an aggregated distribution $[8,20]$. Initial colonizing CBB produce odors that attract other females explaining the aggregation behavior [44]. CBB infestations (hot spots) are most common in areas with elevated shade or humidity [20]. In Colombia, CBB "hot spots" are observed in the edges (first three rows) and depressions or lower areas of plantations older than 3 years [33]. As the population increases, the spatial distribution of CBB becomes more regular. In Guatemala, infestation levels $>10 \%$ showed a non-aggregated spatial distribution [55]. In general, high risk areas for CBB infestation occur adjacent to facilities where the harvested coffee is processed and near roads close to buildings and neighbor coffee plantations. Therefore, monitoring efforts should be intensified in these locations, especially during harvest when berries are moved.

\subsection{Effect of Seasonal Rainfall}

During the rainy season, CBB populations are often reduced since wet conditions promote natural mortality factors. For example, fallen berries decompose faster thus limiting the period for emergence [56]. Wet and humid conditions promote entomopathogenic fungi such as Beauveria bassiana (Balsamo-Crivelli) Vuillemin, Metarhizium brunneum (Petch), Isaria fumosorosea (Wize), and Lecanicillium lecanii (Zimm.) (Viégas) which infect CBB $[3,7,8,57]$. Dry seasons promote the reproduction of CBB on fallen berries or left on the trees. However, a prolonged dry season may reduce CBB populations, since the beetle is sensitive to berry desiccation [8,36]. In Hawaii coffee is planted at different elevations. Plantations at lower elevation during the dry season may see higher reproduction and dispersal of $\mathrm{CBB}$, making its control more challenging. In Pahala and Hilo, precipitation and the number of cloudy days is higher than in the Kona coffee region, which may improve the use of B. bassiana against CBB.

\subsection{Effect of Shade on $C B B$}

Several authors reported highest CBB infestations in plantations grown under shade [58-62]. According to Vega et al. [3], the CBB evolved in the shade forest in Africa and the insect is better adapted to environments with associated high humidity. However, coffee plantations grown with shade trees have an advantage in that B. bassiana may work better as an insecticide in those conditions. Vega et al. [3] report additional benefits provided by shade trees, including prevention of soil erosion, higher biodiversity, improvement in organic matter, and reduced temperature. In addition, shade trees are a requirement for organic coffee production and support the biodiversity of natural enemies of CBB such as birds, predators (ants and beetles), and parasitoids. For example, coffee plantations located in Captain Cook and South Kona, Hawaii, are grown with macadamia trees, Macadamia spp. F. Muell (Proteales: Proteacea) [63].

\section{Strategies on Integrated Pest Management}

Components of IPM for CBB include sampling and monitoring, cultural harvesting, use of B. bassiana, post-harvest control, release of parasitoids, and pest management during "zoqueo". Many studies report the effectiveness of individual management components for CBB from different regions $[3,7-9,17,18,51,64-66]$. However, few report the effectiveness of multiple components applied as an IPM program $[7,33,67,68]$. Moreover, from 1865 publications of CBB [69], few reports compare the costs of different management strategies for CBB, [7,8,68,70-73].

The goal of coffee farmers is the production of high quality coffee at the best market price produced at lowest cost. In Hawaii, most coffee is sold as "specialty" coffee, which commands a price premium. However, the CBB reduces quality and price, causing loses of yields, and increased costs [74]. According to Shriner [75], before CBB arrived to Hawaii (2010), "Extra Fancy" comprised $25 \%$ of the Kona crop. However, from 2011-2013, no coffee was certified above "Prime" (the lowest grade) due to CBB defects. The loss of "Extra Fancy", as well as "Fancy" and "Number One" grades 
was a huge economic blow to the industry's export market [75]. The current levels of coffee infestation as measured by percent CBB infestation in Hawaii in 2014 was 15\% [75] and averaged 20\% in our 2015 survey (Table 1) which indicates the severity of the CBB problem. There are several tools to control the CBB; however, history shows that the successful establishment of an IPM program requires significant implementation $[7,8,68,76]$. An IPM program combines control strategies based on regional phenology and cost/benefit analysis of specific tactics [8,77].

\subsection{Sampling CBB Populations}

An important aspect of an IPM program for CBB is determining the location and infestations levels of the pest, and the degree of berry penetration (Figure 2). According to Bustillo et al. [7], random sampling is the most appropriate method to estimate CBB populations. Several sampling methods for CBB are reported [7,8,78-83]. The thirty tree sampling procedure known as "Cenicafé method" in Colombia [7] was introduced in Hawaii by Luis F. Aristizábal in 2012 [39] (Figure 2A). A brief description of the sampling method follows (1) divide the coffee farm into independent lots according to plantation age; (2) randomly select 30 per 5000 trees; (3) select a representative branch in the middle of the tree containing 30-100 developing berries; (4) examine all green berries for CBB entry hole; (5) record the number of green berries and those with CBB hole; (6) repeat the process moving in a zig-zig pattern through the plantation; (7) calculate percent CBB infestation for each lot.

In addition to calculating infestation severity, the degree of penetration of CBB inside the berry should be evaluated, since this determines the likelihood that insecticides will be effective. For this, 100 infested green berries are collected throughout each coffee lot. A CBB in the AB position indicates that the female beetle initiated penetration but not reached the endosperm. Therefore no oviposition or immature life stages will occur in the berry (Figure 2B). In the AB position, the female is relatively exposed and vulnerable to applications of insecticides, as well as natural enemies (predators and parasitoids). By contrast, a CBB in CD position has entered the endosperm and initiated reproduction (Figure $2 \mathrm{C}$ ). In the $\mathrm{CD}$ position the $\mathrm{CBB}$ and its progeny are protected from insecticides and the only strategies for control are cultural collection of the berries before the CBB progeny emerge or through the establishment of natural enemies (predators and parasitoids). According to Bustillo et al. [7] the thirty tree method allows the identification of "hot spots" in the coffee plantation, which is critical. Application of insecticides (such as B. bassiana), releases of parasitoids and predators or targeted collection of ripe, over-ripe, and raisin berries from trees and the ground should focus on "hot spots".

In Colombia, the criteria to spray insecticides is $>2 \%$ infestation with $>50 \%$ of CBB in $\mathrm{AB}$ position applied within 5 days of monitoring $[7,68]$. In a recent study conducted in over 80 coffee lots, monthly sampling using the 30-tree method and targeted control measures using the AB/CD criteria resulted in dramatically reduced $\mathrm{CBB}$ infestations, while reducing the costs, and increasing the proportion of premium-grown coffee [68]. When executed properly, the 30-tree sample method correlates CBB infestations levels in field and parchment coffee (Figure 3). The localization of pest "hot spots", and the degree of penetration inside berries (positions AB-CD) helps farmers make decisions about control strategies and evaluate the effectiveness of IPM programs. 

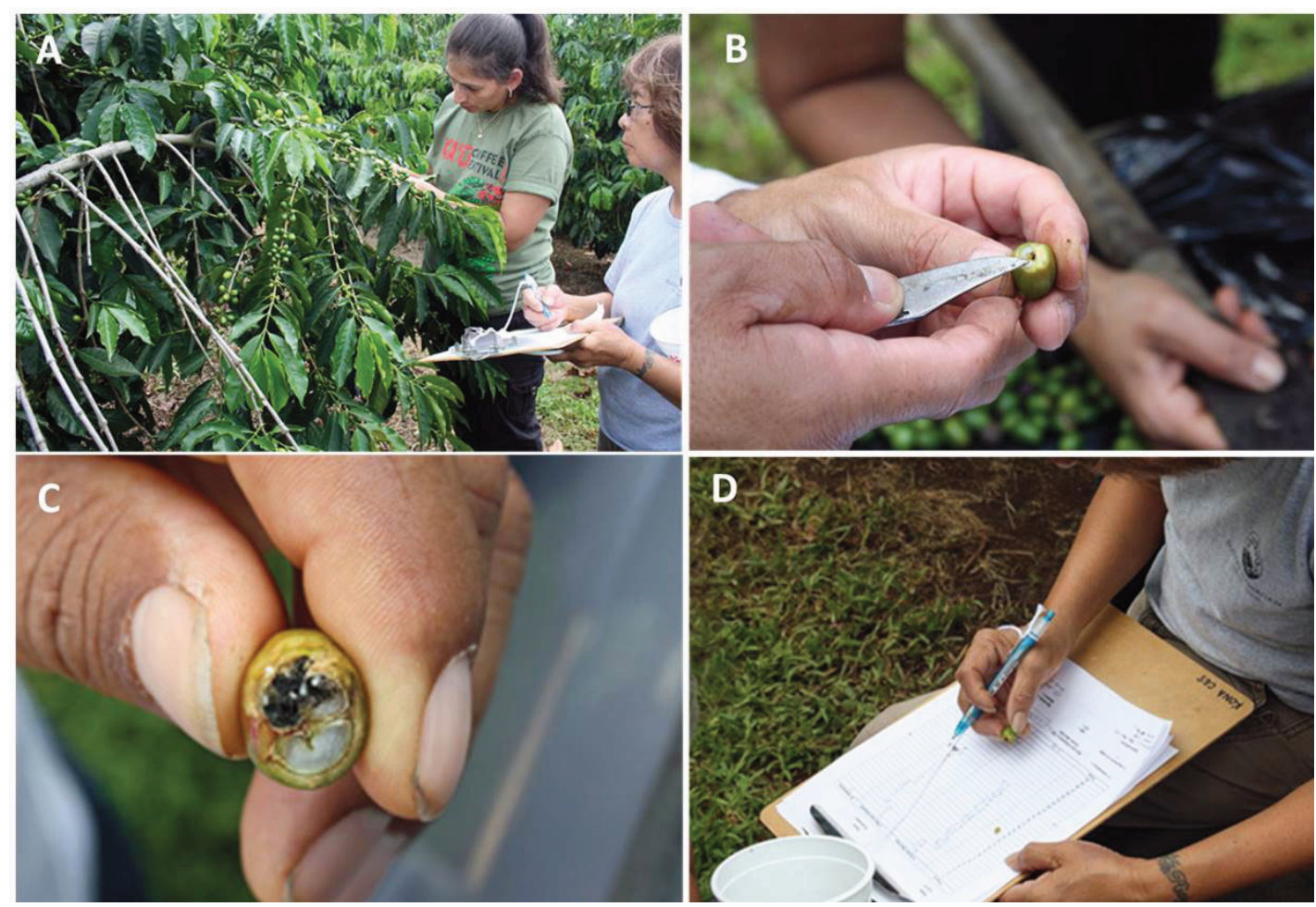

Figure 2. Evaluating the infestation levels of $\mathrm{CBB}(\mathrm{A})$, in position $\mathrm{AB}$ the $\mathrm{CBB}$ is vulnerable to insecticides (B); in the CD position $\mathrm{CBB}$ only can be controlled by removal of berries or natural enemies (C); recording the information (D). Photos taken in Pahala, Hawaii by Juan A. Aristizábal and Luis F. Aristizábal.

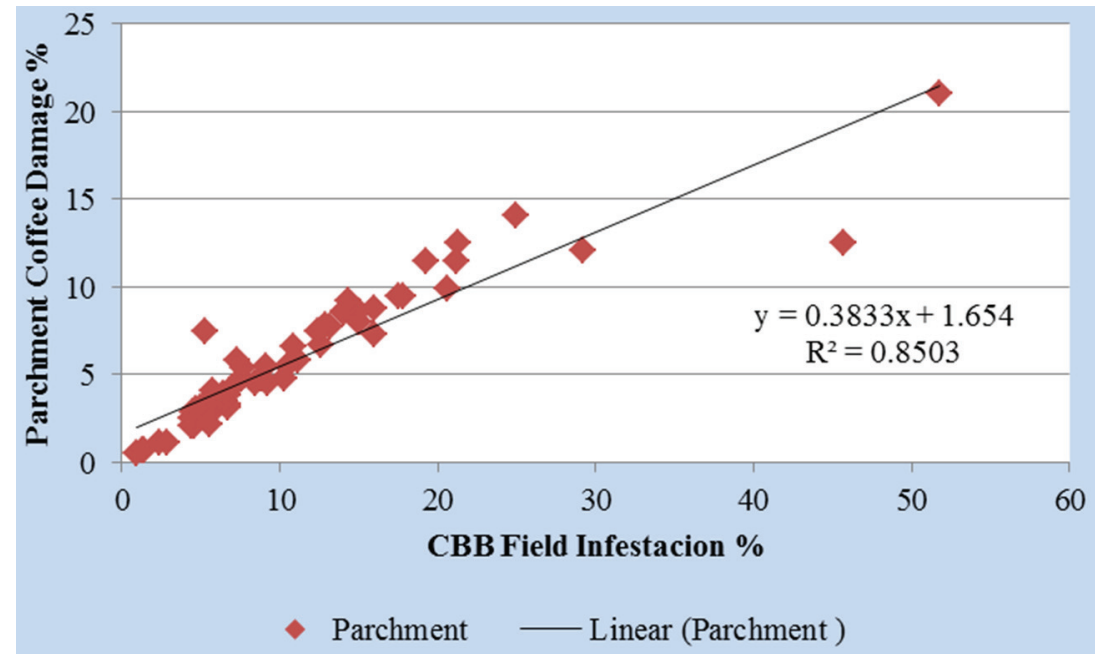

Figure 3. Correlation between CBB infestations levels and damage on parchment coffee. Data from 30 coffee farms in Quindío, Colombia (Source: Aristizábal [84]).

\subsection{Monitoring CBB with Alcohol Traps}

Alcohol traps have been used to monitor the seasonal flight activity of CBB in Central and South America $[49-54,85]$. The lure is typically enclosed in a semi-permeable plastic membrane that allows release of alcohols at an optimal rate of $186 \mathrm{mg} /$ day [50]. The effectiveness of traps is optimized by color (red or white), the mixture of alcohols (ethanol: methanol; in a 3:1 or 1:1 ratio), and location 
(0.5-1.5 $\mathrm{m}$ high). However trap efficiency is influenced by other factors, including weather conditions, and pest infestation levels [35,50,52,86-90].

Traps are used to estimate periods of CBB dispersal. In Brazil, highest CBB activity was observed during the postharvest period (August to February), with peaks during October and November [85]. In the central coffee region of Colombia, highest flight activity was observed January to March [54]. Capture rates up to $6120 \mathrm{CBB}$ per trap/week were observed in farms with high infestation $(17 \%-28 \%$ of berries) [54]. In Hawaii, peak CBB activity was observed in November (south Kona) and January (central Kona), during the peak and late harvest periods respectively [35]. Messing [35] reported that plastic pouch with mixture of alcohols were more effective baits compared with open vials of alcohols. Through early detection of seasonal flight activity, coffee farmers can make better control decisions by applications of B. bassiana with high activity of CBB.

\subsection{Cultural Control Practices}

Before CBB was detected in Colombia in 1988, about $10 \%$ of coffee berries were left on trees and the ground after harvesting [91]. Coffee farmers did not consider this loss significant. However, after CBB was detected, this situation changed, since the residual coffee berries became the main reservoir of CBB that infested new coffee berry cycles [7]. Under Colombian conditions, where several flowering cycles occurs during the year, but only two harvest periods, the control of CBB was challenging. Since all CBB life stages occur inside a berry, removing infested berries became the goal. Regular harvesting of ripe, over-ripe, and raisin (dried) berries during harvest periods reduced CBB from $70 \%$ to $<6 \%$ infested berries [92]. The practice of frequent (2-3 week intervals) and more efficient harvesting has become a primary tool to manage CBB in Colombia [7,67,73,93-95]. A similar situation of continuous flowering/production cycles of coffee was observed in Pahala and elevated coffee plantations in Kona, Hawaii (Figure 4A). Therefore, increased frequency and efficacy of harvesting mature, over-ripe, and raisin berries is a strategy that needs to be evaluated under Hawaiian conditions. Since labor (harvest workers) is more expensive in Hawaii compared with Colombia and other countries in Latin America, the cost/benefit aspects of cultural harvesting versus other control strategies needs to be evaluated.

The success of cultural harvesting depends on how efficiently ripe, over-ripe and raisin berries are collected [7,67]. According to Bustillo et al. [7], the goal is $<5$ such berries per tree, with $>10$ berries resulting in an ineffective practice, while $6-10$ berries/tree means that cultural control is partially effective. Working with coffee farmers through a participatory research program, Aristizábal et al. $[73,76,95]$ reported significant control of CBB over two years though effective harvesting alone. In another example, the control of CBB on an 110 ha specialty coffee farm in Colombia was significantly enhanced through training harvest workers to improve their cultural harvesting effectiveness. Results showed that trained workers left an average of 6.5 berries per tree postharvest, down from 22.5 berries per tree, resulting in $0.7 \%$ CBB damage on parchment coffee, down from $2.3 \%$ prior to training [68]. 


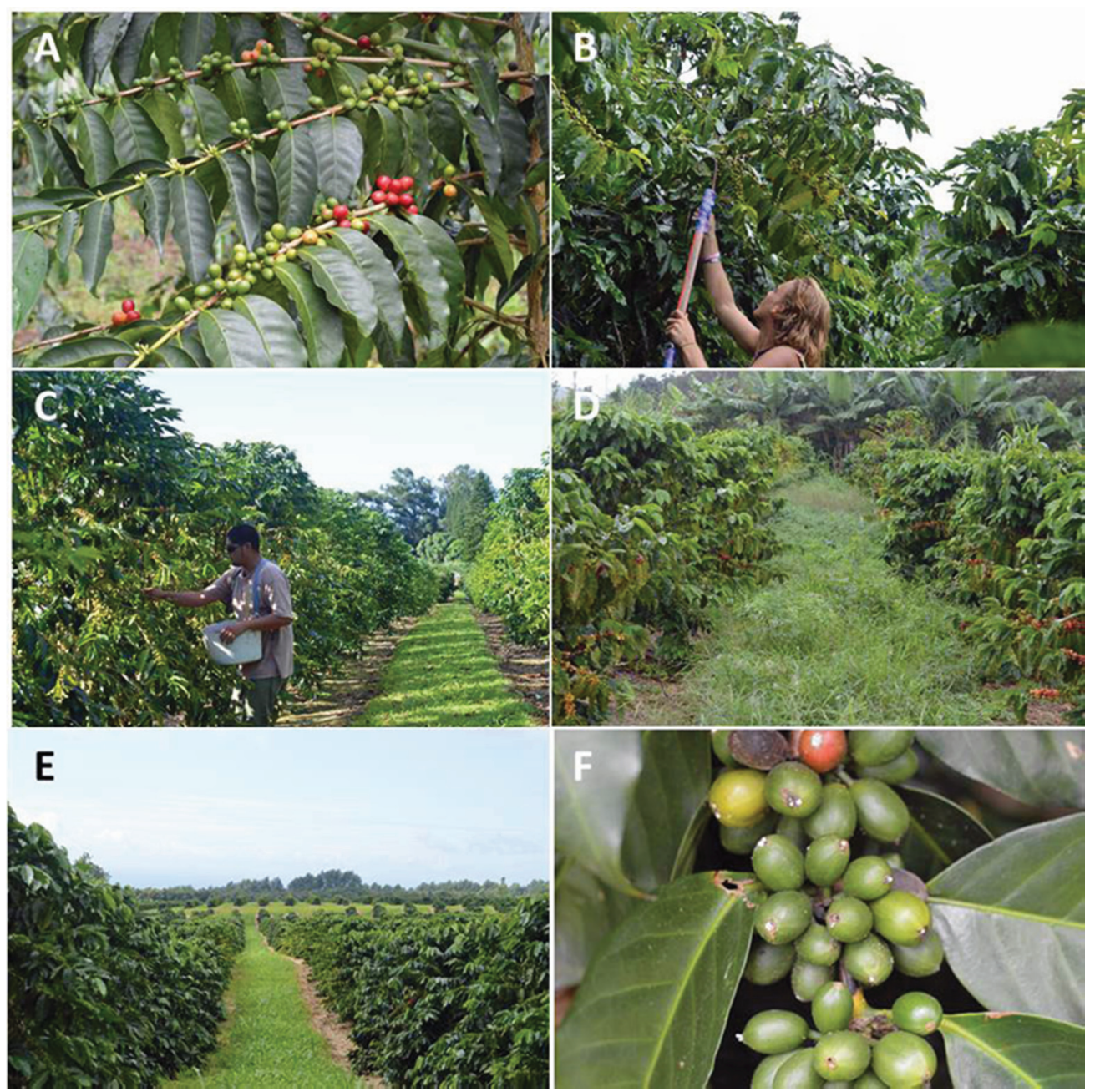

Figure 4. Coffee tree with berries at developmental stages from flowering to maturity (A); tall trees with many verticals and narrow spacing $(<2 \mathrm{~m})$ makes collection difficult $(\mathbf{B})$; trees with $<4$ verticals and spacing $>2 \mathrm{~m}$ simplifies harvest $(\mathbf{C})$; weeds obscure fallen berries (D); weed management facilitate harvesting (E); CBB in AB position infected by B. bassiana (F); Photos taken in Pahala, Hawaii, by Libia C. Mahé, and Luis F. Aristizábal.

Similar reports have emerged from other countries where cultural harvesting (re-picking) is implemented. In Brazil [96] and Guatemala [70], improved CBB control occurred when re-picking after harvest was conducted. In Mexico, the re-picking practice was as effective as two applications of insecticides in the control of CBB [71].

In Hawaii, most coffee pickers are Hispanic or Micronesian (Pacific Islander) and typically paid high wages (US \$0.60/pound or higher during the main season and hourly US \$12-15 at other off-peak times [75]. Further, few coffee farmers train pickers according to the criteria outlined above. For example, between 20 and 45 berries left per tree and $>23$ berries on the ground per tree were observed after a round of harvest in coffee farms in Pahala and Kona, Hawaii [63]. Under this scenario control of CBB would be difficult even if insecticides were applied frequently. Training workers to collect old berries, and prevent fallen berries, is needed in Hawaii. However, training pickers may be a challenge due to a shortage of laborers and difficulty retaining them. There is also a language barrier, primarily for Micronesian laborers [75], for those reasons, farmers may have difficulty enforcing standards.

In Hawaii, a "sanitation" involving the total removal of berries at the end of harvest season [39], may not apply for some regions such as Pahala, Kona and other elevated plantations due to continuous flowering and berry presence all year [63]. In some cases, coffee farmers may wait until infested 
developing berries become mature for harvesting. Since CBB generally only infests one of the two endosperm seeds (coffee berry), farmers can save $50 \%$ of an infested berry. In addition, there are more life stages of CBB on a raisin (46.3 individual per berry), over-ripe (23.4), and mature (9.1) berries than in a green berry (2.9) [7]. This means that over-ripe and raisin berries should be preferentially collected during harvesting. Therefore, coffee farmers and pickers should understand that collecting mature, over-ripe, and raisin berries and preventing berries falling during harvest will control CBB populations. Other aspects that will influence the effectiveness of harvesting and insecticidal control include (1) the distribution and density of the coffee trees; (2) the number of vertical branches (shoot growth) per tree (Figure 4B,C); (3) weed control which enhances collection of berries on the ground (Figure 4D,E) and (4) optimal fertilization to promote high production and quality coffee.

\subsection{Use of B. bassiana}

The entomopathogenic fungus Beauveria bassiana naturally infects CBB in countries including Brazil [97,98] Ecuador [56], Colombia [99], Honduras [100], Mexico [101], Costa Rica [102], and Puerto Rico [103]. The natural occurrence of B. bassiana infecting CBB is variable, and has been reported at $<1 \%$ beetles in Brazil [104], but higher in other regions, i.e., 44\% in Nicaragua [105], 60\% in India [106] and reached $71 \%$ in a study in Cameroon [107]. The fungus has been developed as an environmentally safe bioinsecticide that is sprayed against CBB but is not toxic to workers and has low impact on non-target organisms including CBB natural enemies. The effectiveness of $B$. bassiana under field conditions depends of several factors, including the strain, concentration, virulence, weather conditions, and application efficiency $[7,8,108-111]$. Previous reports document CBB sprayed with B. bassiana under field conditions in Colombia achieved infection rates of 69\% [112], 91\% [113], 64\% [114] and 67\% [115]. Cruz et al. [116] stated that mixtures of B. bassiana strains may result in synergism against CBB. Spraying B. bassiana is another strategy to control CBB in fallen berries [117-119]. Using this approach, the CBB population was reduced by $75 \%$ on fallen berries [114]. Recent research has focused on the use of B. bassiana as a fungal endophyte (colonizing live coffee plants) [120-122]. Although B. bassiana was confirmed as a viable endophyte in inoculated plants, its establishments was relatively short lived (<6 months) [121].

According to Hollingsworth [123], in Hawaii, there is concern about native insects. Initially B. bassiana was classified as a "restricted" microorganism in the Islands, meaning that it could be initially imported under permit for research, but not used commercially. In February 2011, based on the need and safety assessment, the Hawaii Board of Agriculture permitted products containing the GHA strain to be imported and used by growers [123]. There is currently a voluntary federal subsidy program for growers to apply B. bassiana in plantations infested by CBB [75]. According to Shriner [75], currently, close to 4700 acres (out of an estimated 6000) have contracted to the subsidy program. Participating growers are required to monitor using the 30 -tree method before receiving the B. bassiana product, and instructed how to apply to optimize its effectiveness [75]. Early field trials with commercial products showed infections between $25 \%-45 \%$ of founder CBB females on green berries during peak fight activity [124]. The author's survey of different farms showed variable infection rates $(9 \%-67 \%$ ) (Table 1; Figure $4 \mathrm{~F}$ ). Improvements in the use of B. bassiana as a biopesticide and potential endophyte are warranted to increase its effectiveness under Hawaiian conditions.

\subsection{Post-Harvest Control}

Practical methods to prevent re-infestation of CBB include sanitation measures to reduce its escape from harvesting facilities. Tying burlap or plastic bags used by pickers, moving bags from the field to the wet mill twice per day, screening the wet mill, covering silos and pulp pits with transparent plastic smeared with grease, and drying parchment coffee inside screened greenhouses are useful measures $[7,64,125]$. CBB-infested berries that are separated post-harvest can be treated with hot water to prevent CBB escape. In Colombia, the lead author conducted participatory research with coffee farmers to improve postharvest control measures that resulted in a significant reduction of $\mathrm{CBB}$ 
escape from processing facilities $[64,126]$. Alcohol-traps can also be used in processing areas to capture residual CBB. There are opportunities to improve post-harvest control in Hawaii (Figure 5).

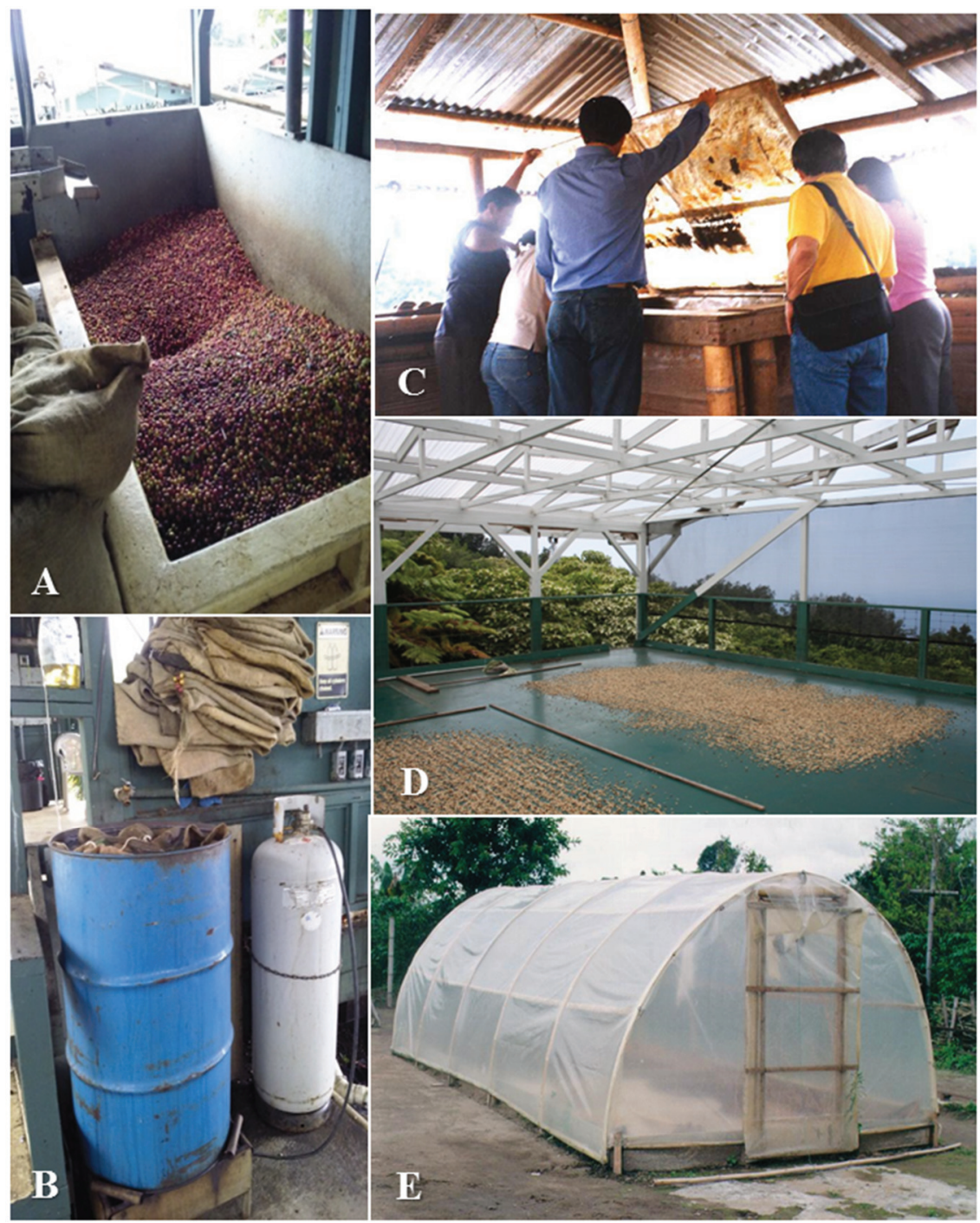

Figure 5. Silos used to process harvested coffee without cover allows escape of CBB (A), container with hot water to control CBB in harvest bags (B); silo cover with transparent plastic smeared with grease to capture CBB in Colombia (C); drying parchment coffee in open areas allow escape of CBB (D); and enclosure for dry parchment coffee used to prevent CBB escape in Colombia, (E). Coffee plantations in Kona, Hawaii and in Quimbaya, Colombia. Photos taken by Luis F. Aristizábal.

\subsection{Natural Enemies of $C B B$}

The identification of specialist parasitoids and predators of the CBB in its endemic region has been used to establish classical biological control programs. Three African parasitoids were introduced to Latin America against established CBB populations: Cephalonomia stephanoderis, and Prorops nasuta both (Hymenoptera: Bethylidae), are ecto-parasitoids of CBB larvae and pupae, while Phymastichus coffea (Hymenoptera: Eulophidae) is an endo-parasitoid of adults [127-131]. Despite initial difficulties [8,129], C. stephanoderis and P. nasuta became established several years after their introduction in Brazil [132], Ecuador [133] Guatemala [134], Mexico [135,136], and Colombia [137,138], The parasitoid P. nasuta survived cold temperatures, dry seasons, and pressures from insecticide applications against CBB in Brazil for more than 40 years after its introduction in 1929 [132]. In addition, P. nasuta proved to be 
better adapted to Colombia coffee plantations compared with C. stephanoderis [137-139]. By contrast, C. stephanoderis but not $P$. nasuta become established in Mexico [135,136,140].

The level of control achieved in CBB from these exotic parasitoids has been variable. In Ecuador C. stephanoderis parasitism rates ranged from 9\%-52\% [141], in Mexico from $1 \%-20 \%$ [20], and in Colombia 3\%-65\% [142]. Significant reduction of CBB by C. stephanoderis was reported in Mexico [143], and Colombia [144-146]. Parasitism rates from P. nasuta were low in Brazil (>2\%) [147] but higher (27\%) in Ecuador [133] and Colombia (50\%) [138]. The effectiveness of CBB parasitoids was assessed by the primary author in Colombia through participatory research programs with coffee famers. Significant reduction of CBB populations were obtained over two years in 34 small coffee farms by the combined efforts of releasing C. stephanoderis and P. nasuta as well as improving the efficacy of harvesting $[139,148]$. Results showed CBB infestation levels amongst individual farms declined from $7 \%-48 \%$ to $2 \%-4 \%$, while the production of parchment coffee with $<2 \%$ damage similarly declined during this period [139]. Since frequent harvesting may affect the establishment of parasitoids by removing infected CBB, the use of screened enclosures has been proposed [148-150]. These enclosures have holes that allow the escape of parasitoids but not CBB. Placing CBB-infested berries inside the screened enclosures in the field can be used as a conservation biological control strategy to enhance parasitoids and facilitate their establishment $[149,151,152]$.

Once imported, mass production of parasitoids is needed to improve the chance of establishment. For example, when P. coffea was introduced to Colombia from Togo (Africa) a mass production method was developed [131,153], which enabled the species to be transported to other countries in South America as well as India. Phymastichus coffea attacks the CBB female before it initiates oviposition thus preventing damage to berries $[8,66]$. Several studies evaluated the effectiveness and establishment of $P$. coffea in Colombia [66,154-156]. High parasitism rates $(85 \%)$ were initially reported by Jaramillo et al. [66]. However, several years after its introduction, P. coffea could not be found [115]. In Mexico, P. coffea also did not establish [157]. Climate may play an important role in the establishment of this endo-parasitoid.

The USDA-ARS is seeking permits to introduce and test CBB parasitoids in Hawaii under quarantine conditions against potential non targets, including 20 native Xyleborus spp. [123]. Some locations that have continuous flowering and berries all year (e.g., Pahala and elevated plantations in Kona) may be suitable for their establishment. In addition, feral coffee plantations, which are CBB reservoirs, also may represent good release sites.

Generalist natural enemies of CBB include ants (Solenopsis geminate, Dorymyrmes sp. Pheidole sp. and Mycocepurus smithii in Colombia [158], Tetramorium bicarinatum in Cuba [159]), and the predatory thrips Karnypthrips flaves in Kenya [160,161]. The generalist predator flat bark beetle, Cathartus quadricollis (Coleoptera: Cucujidae), was reported in Colombia [162], Costa Rica [163] and Hawaii [164]. According to Follett [165], currently, C. quadricollis is being reared and released in Hawaii by the USDA in Hilo. Additional evaluations are needed to assess the effectiveness of this predator under different field conditions.

Entomopathogenic nematodes which naturally occur in the soil are potential biological control agents for CBB inside fallen berries $[65,166,167]$. In Colombia field applications of native strains of Heterorhabditis sp. (Rhabditida: Heterorhabditidae) and Steinernema sp. (Rhabditida: Steinernematidae) applied at high rates/volume $\left(1.25-5 \times 10^{5} \mathrm{IJ}\right.$ in $300 \mathrm{~mL} /$ tree $)$ located, infected and reproduced inside CBB causing mortality of $42 \%$ and $34 \%$, respectively, on infested berries on the ground [167]. Lower effectiveness was reported in another study in Hawaii [168] where S. carpocapsae caused 4.7\% and $17.1 \%$ mortality of CBB adults and larvae, respectively, under field conditions. The evaluation of additional native and commercial strains and application strategies for entomopathogenic nematodes in Hawaii is warranted. 


\subsection{Control During "Zoqueo"}

In Colombia, coffee lots are pruned back close to the ground every 5 or 6 years, a practice of rejuvenation known as "zoqueo". While promoting vigorous plants and maintaining manageable sized trees, a major disadvantage of "zoqueo" is that lots are not routinely harvested for one or more years until the coffee production returns to normal. Because CBB management traditionally is not conducted on felled trees (which are not removed), large numbers of CBB may develop on berries and re-infest surrounding areas [8,38]. Measures to control CBB are therefore recommended following "zoqueo". For example, CBB dispersal can be substantially reduced in "zoqueo" lots through using trap trees, and harvesting and applying B. bassiana to these trap trees and ground [169].

In Hawaii, rejuvenation practices known as "Kona Style System" and "Beaumont-Fukunaga System" [39,170], allow pruning by rows of mixed age coffee trees to simplify management and harvesting (Figure 6A,B). Those practices need to be re-examined under the presence of CBB, since a combination of old and new coffee trees in the same lots may promote the dispersal of CBB.
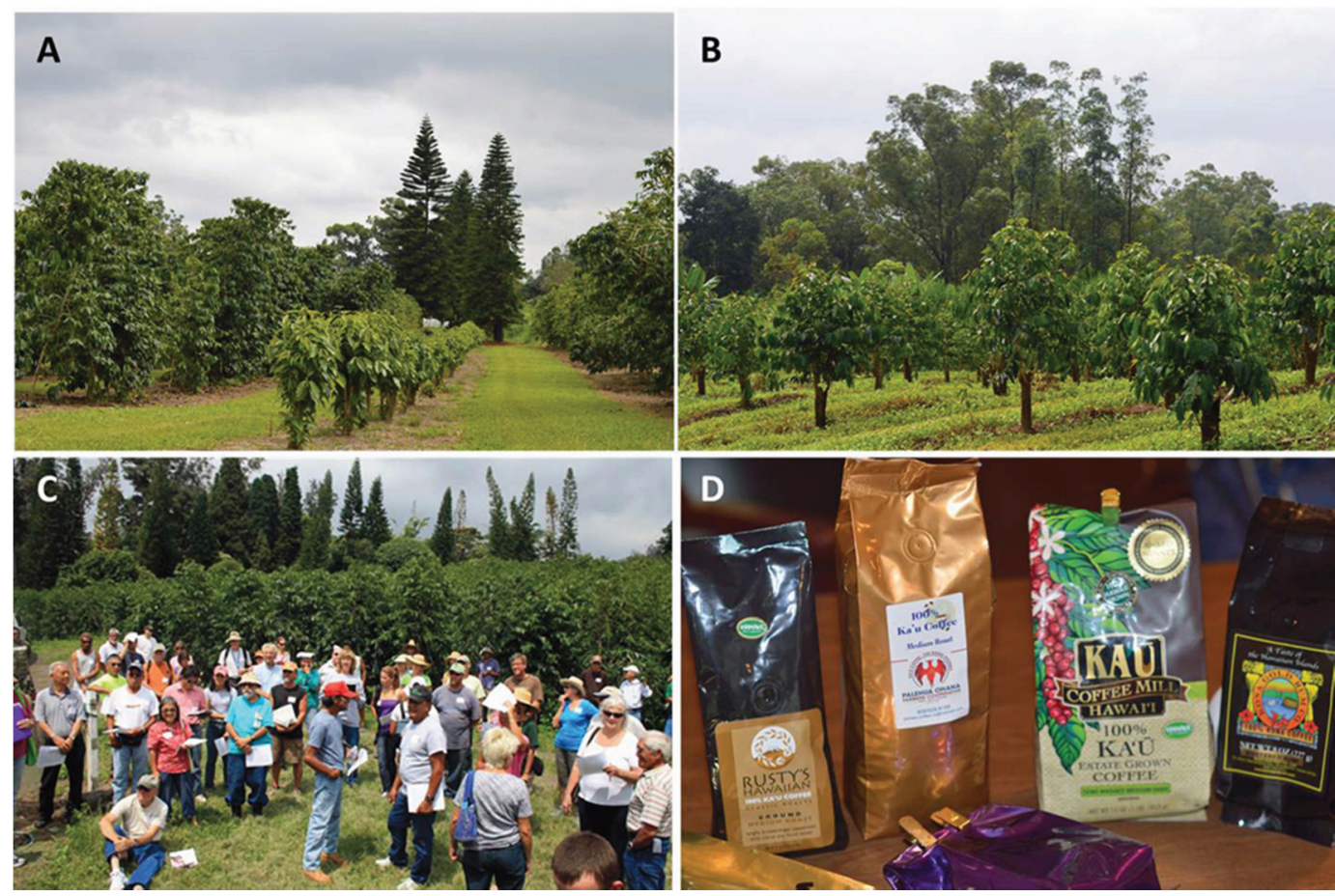

Figure 6. Traditional Kona-style and Beaumont-Fukunaga pruning (A); stump pruning by blocks (B); training coffee farmers and technicians on IPM (C); coffee brands produced in Kau and Kona, Hawaii (D). Coffee plantations in Pahala and Kona, Hawaii. Photos taken by Libia C. Mahé and Luis F. Aristizábal.

\section{General Recommendations}

\subsection{Recommendation to Coffee Farmers}

There is currently no clear strategy to eradicate the CBB once it becomes established. Therefore, coffee farmers need to learn how to produce high quality coffee in the presence of this pest (Figure 6C,D). Recommended strategies include delegating someone to supervise and record all activities related to the control of CBB. In small coffee farms, the owner or family member should assume this role. Applying fertilizers correctly, controlling weeds, pruning verticals, and maintaining irrigation are important to maintain healthy coffee trees.

The coffee plantation should be divided into management blocks containing coffee lots of similar age. Infestation levels of CBB should ideally be monitored in each coffee lot monthly using the 30-tree 
method (see Section 3.1). An electronic log of pest infestation levels (including zeros) should be maintained. This will highlight high risk areas (which can receive additional scrutiny and provide good locations to place traps). Any 'hot spots' should be identified and targeted for control measures. B. bassiana or other pesticide should be applied in coffee lots with $>2 \%$ infestation and $50 \%$ of CBB in an $A B$ position. An approved surfactant will help increase the efficiency of the spray. For rejuvenation of coffee trees, stump pruning by blocks is recommended; since this practice allows control the CBB and delay the re-infestation for 1-2 years (see Section 3.7).

During harvest periods, all over-ripe, and raisin berries should be collected for disposal. Increasing the frequency of harvesting (especially in hot spots) to every 2-3 weeks will help remove CBB infestations. Pickers should be trained to conduct efficient harvesting, and reduce and collect dropped berries. It is recommended to periodically supervise pickers and evaluate their effectiveness at maintaining $<5$ berries (mature, over-ripe, and raisin) per tree after a harvesting round (see Section 3.3).

Postharvest recommendations include tying and moving bags to the wet mill as soon as possible after collection. A floatation tank can be used to separate raisin berries which should be treated to kill residual CBB, for example by boiling at $50^{\circ} \mathrm{C}$ for $20-30 \mathrm{~min}$. Silos and pulp pits can be covered with a transparent plastic lid smeared with grease to capture emerging CBB. Screening the wet mill and other processing areas and using traps will reduce CBB escape.

\subsection{Recommendation to Extension Technicians}

The Extension service plays an important role in the success of establishing IPM for new invasive pests such as the CBB. In Hawaii, many farmers and technicians have insufficient knowledge about the $\mathrm{CBB}$ and its control measures, which can promote its spread among and between islands. Adapting control strategies for coffee plantation conditions in Hawaii is needed. For example, the physiology of the coffee plant which drives pest cycles will vary across altitudes and locations. It is important to determine seasonal flight activities in different locations and communicate the optimal periods to apply controls measures such as B. bassiana to growers.

The Extension service may provide guidance through Farmer Field Schools. This methodology based on "Learning by doing" allows coffee farmers and workers to understand the CBB problem and practice IPM solutions, and has been successfully implemented in Colombia [76,95,171,172]. Training coffee farmers and pickers is needed. According to grower surveys, cultural harvesting is the IPM component with the highest adoption in Colombia $[173,174]$.

\subsection{Recommendations to Research Centers}

From 1865 articles published on CBB in a recent biography [69], only $42(<2.2 \%)$ included the term "Integrated Pest Management" or "IPM" and only $22(<1.1 \%)$ include the terms "Coffee farmers," or "coffee growers." If coffee farmers are expected to adopt IPM techniques for CBB developed at research centers, they need to be included in the development, and validation of these technologies. Some methods may have a higher impact because results are evident. For example, evaluation of CBB female flight activity using alcohol traps, allows insecticides to be timed correctly. Working with growers to create real-time regional maps of CBB abundance (similar to those achieved with other major pests on IPM PIPE http:/ / www.ipmpipe.org/) might be a worthwhile goal. Planting and monitoring trees as "trap crops" near ports or other strategic areas on non-infested islands should be done to delay CBB establishment in those Islands.

Research should evaluate control measures under local conditions. For example, the effectiveness of $B$. bassiana, entomopathogenic nematodes or other pesticides should be tested in different climatic regions. Cost-benefit analysis of cultural harvesting and other techniques such as vacuum machines to collect fallen berries should be assessed. Improved management of feral plantation should be studied. Research on exotic parasitoids as classical biological control agents and the search for indigenous natural enemies for potential mass rearing, and release against CBB are options to explore. Finally, ecological studies on the CBB in Hawaiian is needed to better understand the pest. 


\section{Conclusions}

Establishment of an IPM program for CBB requires knowledge of the biology, ecology, and behavior of the pest and its relationship with the coffee plant and any alternative hosts. Monitoring CBB populations using the 30-tree method and using traps allows early detection of CBB and location of "hot spots", which can facilitate control decisions. Improvements in the way harvesting and processing is conducted is a big challenge for coffee famers if they want to produce high quality coffees. Harvesting mature, over-ripe, and raisin berries, limiting fallen berries and implementing post-harvest practices is needed. Applications of B. bassiana should be applied when the CBB populations are most vulnerable ( $>2 \%$ infestation of $\mathrm{CBB}$ and $>50 \%$ of $\mathrm{CBB}$ on $\mathrm{AB}$ position). Cooperation between coffee farmers, extension technicians, university researchers, and others is needed to obtain a high adoption and impact on IPM program for CBB.

Acknowledgments: We thank the Kona Coffee Farmers Association, The Kohala Center, The Kona County Farm Bureau, and Buddha's cup coffee farm in Hawaii for hosting LFA in 2012 and 2015. Special thanks to Suzanne Shriner, Melanie Bondera, Nicole Milne, and Bod Nelson [Lehu'ula Farm] for their support during my visits to Hawaii. Thanks to Andrea M. Kawabata at the University of Hawaii, Peter A. Follett, and Robert G. Hollingsworth at USDA-ARS in Hilo, and finally special thanks to coffee farmers in Pahala and Kona, for their valuable collaboration during my visits.

Author Contributions:: Luis F. Aristizábal generated the idea, wrote the first draft, visited coffee farmers to evaluate the CBB situation in Hawaii, took pictures, and conducted data analysis. Alex E. Bustillo contributed bibliography documents and reviewed the manuscript. Steven P. Arthurs revised the manuscript for language and technical accuracy, and compiled the figures.

Conflicts of Interest: The authors declare no conflict of interest.

\section{References}

1. FAOSTAT. Food and Agriculture Organization of the United Nations, Statistics Davison, 2014. Available online: http:/ / faostat.fao.org/ (accessed 20 November 2015).

2. Vega, F.E.; Ebert, A.; Ming, R. Coffee germplasm resources, genomic, and breeding. Plant Breed. Rev. 2008, 30, 415-447.

3. Vega, F.E.; Infante, F.; Johnson, A.J. The genus Hypothenemus, with emphasis on H. hampei, the coffee berry borer. In Bark Beetles, Biology and Ecology of Native and Invasive Species, 1st ed.; Vega, F.E., Hofstetter, R.W., Eds.; Elsevier: London, UK, 2015; Chapter 11; pp. 427-494.

4. ICO, International Coffee Organization. Coffee trade statistics. Available online: http://www.ico.org/ (accessed on 20 November 2015).

5. USDA, United States Department of Agriculture. Coffee: World markets and trade. Available online: http:/ / www.fas.usda.gov/data/coffee-world-markets-and-trade/ (accessed on 20 November 2015).

6. Le-Pelley, R.H. Pests of Coffee; Longmans, Green and Co. Ltd.: London, UK, 1968; p. 590.

7. Bustillo, A.E.; Cárdenas, R.; Villalba, D.; Benavides, P.; Orozco, J.; Posada, F. Manejo Integrado de la Broca del Café, Hypothenemus hampei (Ferrari) en Colombia, 1st ed.; Cenicafé: Chinchiná, Colombia, 1998; p. 134.

8. Baker, P. The Coffee Berry Borer in Colombia. DFID-Cenicafé CABI Bioscience IPM for coffee Project (CNTR 93/1536A); Cenicafé: Chinchiná, Colombia, 1999; p. 154.

9. Damon, A. A review of the biology and control of the coffee berry borer, Hypothenemus hampei (Coleoptera: Scolytidae). Bull. Entomol. Res. 2000, 90, 453-465. [CrossRef] [PubMed]

10. Burbano, E.; Wright, M.; Bright, D.E.; Vega, F.E. New record for the coffee berry borer, Hypothenemus hampei, in Hawaii. J. Insect Sci. 2011. [CrossRef] [PubMed]

11. Baker, P.S. Some aspects of the behavior of the coffee berry borer in relation to its control in southern Mexico (Coleoptera: Scolytidae). Folia Entomol. Mexicana 1984, 62, 9-24.

12. Klein-Koch, C. Natural regulation factors and classical biological control of the coffee berry borer (Hypothenemus hampei Ferrari) in Ecuador. In Proceedings of the International DLG-Symposium on Integrated Pest Management in Tropical and Subtropical Systems, Bad Dürkheim, Germany, 8-15 February 1990; pp. 331-334. 
13. Cárdenas, M.R.; Bustillo, A.E. La broca del café en Colombia. In Proceedings of the Resúmenes, I Reunión Internacional Sobre la Broca del Café, Tapachula, Chiapas, México, 17-22 de noviembre de 1991; Barrera, J.F., Castillo, A., Gómez, J., Malo, E., Infante, F., Eds.; pp. 42-44. (In Spanish).

14. Monterrey, J. La broca del café en Nicaragua. In Proceedings of the Resúmenes, I Reunión Internacional Sobre la Broca del Café, Tapachula, Chiapas, México, 17-22 de noviembre de 1991; Barrera, J.F., Castillo, A., Gómez, J., Malo, E., Infante, F., Eds.; pp. 28-30. (In Spanish).

15. Bergamin, J. Contribuição para o conhecimento da biologia da broca do café Hypothenemus hampei (Ferrari, 1867) (Col. Ipidae). Arquivos do Instituto Biologico São Paulo 1943, 14, 31-72. (In Portuguese).

16. Decazy, B. Descripción, biología, ecología y control de la broca del fruto del cafeto, Hypothenemus hampei (Ferr.). In Proceedings of the 50 años de Cenicafé 1938-1988, Conferencias Conmemorativas; Cenicafé, Chinchiná, Colombia, 14 de octubre al 18 de noviembre 1990; pp. 133-139. (In Spanish).

17. Jaramillo, J.; Borgemeister, C.; Baker, P. Coffee berry borer Hypothenemus hampei (Coleoptera: Curculionidae): Searching for sustainable control strategies. Bull. Entomol. Res. 2006, 96, 223-233. [CrossRef] [PubMed]

18. Vega, F.E.; Infante, F.; Catillo, A.; Jaramillo, J. The coffee berry borer, Hypothenemus hampei (Ferrari) (Coleoptera: Curculionidae): A short review, with recent finding and future research directions. Terrestr. Arthr. Rev. 2009, 2, 129-147.

19. Ruiz-Cárdenas, R.; Baker, P. Life table of Hypothenemus hampei (Ferrari) in relation to coffee berry phenology under Colombian field conditions. Sci. Agric. 2010, 67, 658-668. [CrossRef]

20. Barrera, J.F. Dynamique des Populations du Scolyte des Fruits du Caffeé, Hypothenemus hampei (Coleoptera: Scolytidae), et lute Biologique avec le Parasitoide Cephalonomia stephanoderis (Hymenoptera: Bethylidae), au Chiapas, Mexique. Ph.D. Thesis, Université Paul Sabatier, Toulouse, France, 1994; p. 301. (In French).

21. Baker, P.S.; Barrera, J.F.; Rivas, A. Life-history studies of the coffee berry borer (Hypothenemus hampei, Scolytidae) on coffee trees in southern Mexico. J. Appl. Entomol. 1992, 29, 656-662. [CrossRef]

22. Brun, L.O.; Stuart, J.; Gaudchon, V.; Aronstein, K.; French-Constant, R.H. Functional haplodiploidy: A mechanism for the spread of insecticide resistance in an important international insect pest. Proc. Natl. Acad. Sci. USA 1995, 92, 9861-9865. [CrossRef] [PubMed]

23. Jaramillo, J.; Chabi-Olaye, A.; Kamonjo, C.; Jaramillo, A.; Vega, F.E.; Poehling, H.M.; Borgemeister, C. Thermal tolerance of the coffee berry borer Hypothenemus hampei: Predictions of climate change on a tropical insect pest. PLoS ONE 2009, 4, e6487. [CrossRef] [PubMed]

24. Muñoz, R. Ciclo biológico y reproducción partenogenética del cafeto, Hypothenemus hampei (Ferr.). Turrialba 1989, 39, 415-421. (In Spanish).

25. Giordanengo, P. Biologie, Eco-éthologie et Dynamique des Poppulations du Scolyte des Grains de café, Hypothenemus hampei Ferr. (Coleoptera: Scolytidae), en Nouvelle-Calédonie. Ph.D. Thesis, Université de Rennes I, Rennes, France, 1992. (In French).

26. Arcila, J.; Jaramillo, A.; Baldión, V.; Bustillo, A.E. La floración del cafeto y su relación con el control de la broca. Avances Técnicos Cenicafé 1993, 193, 1-6. (In Spanish).

27. Camayo, G.C.; Arcila, J. Desarrollo floral del cafeto en condiciones de la zona cafetera colombiana (Chinchiná-Caldas). Avances Técnicos Cenicafé 1997, 245, 1-8. (In Spanish).

28. Vélez, B.E.; Jaramillo, A.; Cháves, B.; Franco, M. Distribución de la floración y la cosecha de café en tres altitudes. Avances Técnicos Cenicafé 2000, 272, 1-4. (In Spanish).

29. Jaramillo, A.; Guzmán, O. Relación entre la temperatura y el crecimiento en Coffea arabica L. variedad caturra. Rev. Cenicafé 1984, 35, 57-65. (In Spanish).

30. Salazar, M.R.; Arcila, J.; Riaño, N.; Bustillo, A.E. Crecimiento y desarrollo del fruto del café y su relación con la broca. Avances Técnicos Cenicafé 1993, 194,1-4. (In Spanish).

31. Ruiz, R. Efecto de la Fenología del Fruto del café Sobre los Parámetros de la Tabla de vida de la Broca del Café; Hypothenemus hampei (Ferrari). B.Sc. Thesis, Universidad de Caldas, Manizales, Colombia, 1996; p. 87. (In Spanish).

32. Aristizábal, L.F. Efecto del Parasitoide Cephalonomia stephanoderis (Betrem) (Hymenoptera: Bethylidae) Sobre una Población de Hypothenemus hampei (Coleoptera: Scolytidae) en Condiciones de campo. B.Sc. Thesis, Universidad de Caldas, Manizales, Colombia, 1995; p. 129. (In Spanish).

33. Bustillo, A.E. El manejo de cafetales y su relación con el control de la broca del café en Colombia, 1st ed.; FNC-Cenicafé: Chinchiná, Colombia, 2002; p. 40. (In Spanish) 
34. Sponagel, K.W. La broca del Café Hypothenemus hampei en Plantaciones de Café Robusta en la Amazonía Ecuatoriana. Ph.D. Thesis, Universidad de Giessen, Giessen, Germany, 1994; p. 279, (In German and Spanish).

35. Messing, R.H. The coffee berry borer (Hypothenemus hampei) invades Hawaii: Preliminary investigations on trap response alternate hosts. Insects 2012, 3, 640-652. [CrossRef] [PubMed]

36. Baker, P.S.; Ley, C.; Balbuena, R.; Barrera, J.F. Factors affecting the emergence of Hypothenemus hampei (Coleoptera: Scolytidae) from coffee berries, Mexico. Bull. Entomol. Res. 1992, 82, 145-150. [CrossRef]

37. Jaramillo, J.; Chabi-Olaye, A.; Borgemeister, C. Temperature dependent development and emergence pattern of Hypothenemus hampei (Coleoptera: Curculionidae: Scolytinae) from coffee berries. J. Econ. Entomol. 2010, 103, 1159-1165. [CrossRef] [PubMed]

38. Castaño, A.; Benavides, P.; Baker, P.S. Dispersión de Hypothenemus hampei en cafetales zoqueados. Revista Cenicafé 2005, 56, 142-150. (In Spanish).

39. Kawabata, A.M.; Nakamoto, S.T.; Curtiss, R.T. Recommendations for coffee berry borer integrated pest management in Hawai'i 2015. Available online: http://www.ctahr.hawaii.edu/oc/freepubs/pdf/IP-33.pdf (accessed on 8 August 2015).

40. Ticheler, J.H.G. Estudio analítico de la epidemiología del escolítido de los granos de café, Stephanoderis hampei Ferr., en Costa de Marfil (Traducción G. Quiceno). Rev. Cenicafé 1963, 14, 223-294. (In Spanish).

41. Mendoza, J.R.; Gomes de Lima, J.O.; Vilela, E.F.; Fantón, C.J. Atratividade de Frutos à Broca-do-Café, Hypothenemus hampei (Ferrari): Estímulos Visuais e Olfativos; Anais: Londrina, Brasil, 2000; UFPR-IAPAR-IRD; pp. 313-331. (In Portuguese)

42. Mathieu, F.; Gaudichon, V.; Brun, L.O.; Frérot, B. Effect of physiology status on olfactory and visual responses of females Hypothenemus hampei during host plant colonization. Physiol. Entomol. 2001, 26, 186-193. [CrossRef]

43. Vega, F.E.; Simpkins, A.; Bauchan, G.; Infante, F.; Kramer, M.; Land, M.F. On the eyes of male coffee berry borers as rudimentary organs. PLoS ONE 2014, 9, e85860.

44. Giordanengo, P.; Brun, L.O.; Frérot, B. Evidence for allelochemical attraction of the coffee berry borer Hypothenemus hampei, by coffee berries. J. Chem. Ecol. 1993, 19, 763-769. [CrossRef] [PubMed]

45. Mandelsham, M.Y.; Wood, S.L. Bark and ambrosia beetles of South America (Coleoptera: Scolytidae), Brigham Young University, Provo. 2007, p. 900. Available online: http://www.maik.ru/abstract/enteng/9/ enteng0245_abstract.pdf (accessed on 3 July 2015).

46. Mendesil, E.; Bruce, T.J.A.; Woodcock, C.M.; Caulfield, J.C.; Seyoum, E.; Pickett, J.A. Semiochemicals used in host location by the coffee berry borer Hypothenemus hampei. J. Chem. Ecol. 2009, 35, 944-950. [CrossRef] [PubMed]

47. Cruz, R.E.N.; Malo, E.A. Chemical analysis of coffee berry borer volatiles that elicit an antennal response from the coffee berry borer Hypothenemus hampei. J. Mexican Chem. Soc. 2013, 57, 321-327.

48. Ortiz, A.; Vega, F.E.; Posada, F.J. Volatile composition of coffee berries at different stages of ripeness, and their possible attraction to the coffee berry borer Hypothenemus hampei (Coleoptera: Curculionidae). J. Agric. Food Chem. 2004, 52, 5914-5918. [CrossRef] [PubMed]

49. Gutierrez-Martinez, A.; Ondarza, R.N. Kairomone effect of extracts from Coffea canephora over Hypothenemus hampei by coffee berries. J. Chem. Ecol. 1996, 25, 96-100.

50. Borbón, O.; Mora, A.O.; Oehlschlager, A.C.; González, L.M. Proyecto de Trampas, Atrayentes y Repelentes para el Control de la Broca del Fruto de Cafeto, Hypothenemus hampei (Ferrari) (Coleoptera: Scolytidae); Informe ICAFE: San José, Costa Rica, 2002; p. 18. (In Spanish)

51. Dufour, B.P.; Frérot, B. Optimization of coffee beery borer, Hypothenemus hampei Ferrari (Coleoptera: Scolytidae), mass trapping with an attractant mixture. J. Appl. Entomol. 2008, 132, 591-600. [CrossRef]

52. Silva, F.C.D.; Ventura, M.U.; Mikami, A.Y.; da Silva, F.C.; Morales, L. Capture of Hypothenemus hampei Ferrari (Coleoptera: Scolytidae) in response to trap characteristics. Sci. Agric. 2006, 63, 567-571. [CrossRef]

53. Fernandes, F.L.; Pocanço, M.C.; Campos, S.O.; Bastos, C.S.; Chediak, M.; Guedes, R.N.C.; Da Silva, R.S. Economic injury level for the coffee berry borer (Coleoptera, Curculionidae: Scolytinae) using attractive traps in Brazilian coffee fields. J. Ecol. Entomol. 2011, 104, 1909-1917. [CrossRef]

54. Aristizábal, L.F.; Jiménez, M.; Bustillo, A.E.; Trujillo, H.I.; Arthurs, S.P. Monitoring coffee berry borer, Hypothenemus hampei (Coleoptera: Curculionidae), populations with alcohol-baited funnel traps in coffee farm in Colombia. Fla. Entomol. 2015, 98, 381-383. [CrossRef] 
55. Ochoa, H.; Decazy, B.; Lotode, R. Estudio de un tipo de muestreo para determinar el índice de combate de la broca del café Hypothenemus hampei Ferr. Rev. Cafetalera 1988, 287, 16-25. (In Spanish).

56. Klein-Koch, C.; Espinoza, O.; Tandazo, A.; Cisneros, P.; Delgado, D. Factores naturales de regulación y control biológico de la broca del café (Hypothenemus hampei Ferr.). Sanidad Vegetal 1988, 3, 5-30. (In Spanish).

57. Vega, F.E.; Mercadier, G.; Damon, A.; Kirk, A. Natural enemies of the coffee berry borer, Hypothenemus hampei (Ferrari) (Coleoptera: Scolitidae) in Togo and Ivory Coast, and additional entomofauna associated with coffee beans. Afr. Entomol. 1999, 7, 243-248.

58. Mendes, C.T. A broca do café. Revista Agric. (Piracicaba) 1938, 13, 405-423. (In Portuguese).

59. Fonseca, J.P. A “bróca” e o sombreamento dos cafezais. O Biologico (Brazil) 1939, 5, 1336. Rev. Appl. Entomol., Ser. A 1940, 28-61. (In Portuguese).

60. Hargreaves, H. Coffee-pests. In Agriculture in Uganda; Tothill, J.D., Ed.; Oxford University Press: London, UK, 1940; pp. 340-380.

61. Féliz Matos, D.; Guharay, F.; Beer, J. Incidencia de la broca (Hypothenemus hampei) en plantas de café a pleno sol y bajo sombra de Eugenia jambos y Gliricidia sepium en San Marcos, Nicaragua. Agrofor. Am. 2004, 41/42, 56-61. (In spanish).

62. Bosselmann, A.S.; Dons, K.; Oberthur, T.; Olsen, C.S.; Reabild, A.; Usma, H. The influence of shade trees on coffee quality in small holder coffee agroforestry in Southern Colombia. Ecosyst. Environ. 2009, 129, 253-260. [CrossRef]

63. Aristizábal, L.F.; Mid-Florida Research and Education Center, University of Florida, Apopka, FL, USA. Personal Communication, 2015.

64. Salazar, E.H.M.; Aristizábal, L.F.; Mejía, C.G. Investigación participativa con caficultores en relación con el manejo integrado de la broca del café Hypothenemus hampei (Ferrari) (Coleoptera: Scolytidae) durante el proceso de beneficio. Rev. Colomb. Entomol. 2003, 29, 57-62. (In Spanish).

65. Bustillo, P.A.E. Una revisión sobre la broca del café, Hypothenemus hampei (Coleoptera: Curculionidae, Scolytinae), en Colombia. Rev. Colomb. Entomol. 2006, 32, 101-116. (In Spanish).

66. Jaramillo, J.; Bustillo, A.E.; Montoya, E.C.; Borgemeister, C. Biological control of the coffee berry borer Hypothenemus hampei (Ferrari) (Coleoptera: Curculionidae, Scolytinae) by Phymastichus coffea LaSalle (Hymenoptera: Eulophidae) in Colombia. Bull. Entomol. Res. 2005, 95, 1-6. [CrossRef]

67. Benavides, P.; Bustillo, A.E.; Montoya, E.C.; Cárdenas, R.; Mejía, C.G. Participación del control cultural, químico y biológico en el manejo de la broca del café. Rev. Colomb. Entomol. 2002, 28, 161-166. (In Spanish).

68. Aristizábal, L.F.; Lara, O.; Arthurs, S.P. Implementing an integrated pest management for coffee berry borer in a specialty coffee plantation in Colombia. J. Integ. Pest Mngmt. 2012. [CrossRef]

69. Pérez, J.; Infante, F.; Vega, F.E. A coffee berry borer (Coleoptera, Curculionidae: Scolytinae) bibliography. J. Insect Sci. 2015. [CrossRef] [PubMed]

70. Zelaya, R.R.; Vargas, J.C. Rentabilidad del control cultural de la broca del fruto del cafeto (H. hampei) en parcelas de comprobación. In Proceedings of the Taller Regional de Broca (3), IICA-Promecafé, Antigua, Guatemala, 3-7 Abril 1989; pp. 97-102. (In Spanish).

71. Villanueva, E. Efectividad del control manual y químico para la broca del café, $H$. hampei en el Soconusco, Chiapas, México. In Proceedings of the Taller Regional sobre la Broca del Fruto del Cafeto (4), IICA-Promecafé, San Salvador, El Salvador, 1990. (In Spanish).

72. Duque, H.; Baker, P. Devouring Profit; The Soci-Econimics of Coffee Berry Borer IPM; The Commodities Press: CABI-Biosciense, Cenicafé, Chinchiná \& Colombia, 2003.

73. Aristizábal, L.F.; Jiménez, M.; Bustillo, A.E.; Arthurs, S.P. Monitoring cultural practices for coffee berry borer Hypothenemus hampei (Coleoptera: Curculionidae: Scolytinae) management in a small coffee farm in Colombia. Fla. Entomol. 2011, 94, 686-687.

74. Woodill, A.J.; Hemachandra, D.; Nakamoto, S.T.; Leung, P.S. The economics of coffee production in Hawai'i. College of Tropical Agriculture and Human Resources, University of Hawai'i. Economic Issues, July 2014. EI-25. 2014, 1-9.

75. Shriner, Z.; Synergistic Hawaii Ag Council, Kona Hongwanji, HI, USA. Personal Communication, 2016.

76. Aristizábal, L.F.; Salazar, H.M.; Mejia, C.G. Cambios en la adopción de los componentes del manejo integrado de la broca del café, Hypothenemus hampei (Coleoptera: Scolytidae) a través de metodologías participativas. Rev. Colomb. Entomol. 2002, 28, 153-160. (In Spanish). 
77. Kogan, M. Integrated pest management: Historical perspectives and contemporary developments. Ann. Rev. Entomol. 1998, 43, 243-270. [CrossRef] [PubMed]

78. Barrera, J.F.; Infante, F.; Gómez, J.; de la Rosa, W. Guía Práctica Umbrales Económicos para el Control de la Broca del Café; Centro de Investigaciones Ecológicas del Sureste: Tapachula, Chiapas, México, 1993; p. 50. (In Spanish)

79. Muñoz, R. Muestreo en fincas para determinar la población de broca (Hypothenemus hampei Ferr.) y metodología para calcular el nivel de daño económico. Boletín de PROMECAFE, 1988, 38, 4-14. (In Spanish).

80. Baker, P.S. A sampling plan for a control project against the coffee berry borer (Hypothenemus hampei) in Mexico. Tropical Pest Mngmt. 1989, 35, 169-172. [CrossRef]

81. Decazy, B. Métodos de muestreo para la determinación de poblaciones críticas de la broca del fruto del cafeto Hypothenemus hampei (Ferr.). pp. 140-145. In Proceedings of the 50 años de Cenicafé 1938-1988, Conferencias Conmemorativas; Cenicafé, Chinchiná, Colombia, 14 de octubre al 18 de noviembre 1990; p. 255. (In Spanish).

82. Segura, H.R.; Barrera, J.F.; Morales, H.; Nazar, A. Farmer's perceptions, knowledge, and management of coffee pest and diseases and their natural enemies in Chiapas, Mexico. J. Econ. Entomol. 2004, 97, 1491-1499. [CrossRef] [PubMed]

83. Trujillo, E.H.I.; Aristizábal, A.L.F.; Bustillo, P.A.E.; Jiménez, Q.M. Evaluación de métodos para cuantificar poblaciones de broca del café, Hypothenemus hampei (Ferrari) (Coleoptera: Curculionidae: Scolytinae) en fincas de caficultores experimentadores. Rev. Colomb. Entomol. 2006, 32, 39-44. (In Spanish).

84. Aristizábal, L.F. Mid-Florida Research and Education Center, University of Florida, Apopka, FL, USA, Unpublished data, 2015.

85. Pereira, A.E.; Vilela, E.F.; Tinoco, R.S.; De Lima, J.O.G.; Fantine, A.K.; Morais, E.G.; França, C.F. Correlation between number captured and infestation levels of the coffee berry borer, Hypothenemus hampei: A preliminary basis for an action threshold using baited traps. Int. J. Pest Mngmt. 2012, 58, 183-190. [CrossRef]

86. Mathieu, F.; Brun, L.O.; Marcillaud, C.; Frérot, B. Trapping of the coffee berry borer within a mesh-enclosed environment: Interaction of olfactory and visual stimuli. J. Appl. Entomol. 1997, 121, 181-186. [CrossRef]

87. Dufour, B. Importance du piégeage pour la lutte intégrée contre le scolyte du café, Hypothenemus hampei (Ferr.). Available online: http:/ /agritrop.cirad.fr/508307/ (accessed on 8 July 2015). (In French).

88. Fernández, F.L.; Cordero, J. Evaluación de atrayentes alcohólicos en trampas artesanales para el monitoreao de la broca del cafe, Hypothenemus hampei (Ferrari). Bioagro 2005, 17, 143-148. (In Spanish).

89. Barrera, J.F.; Herrera, J.; Chiu, M.; Gómez, J.; Valle Mora, J. La trampa de una ventana (ECOIAPAR) captura más broca del café Hypothenemus hampei que la trampa de tres ventanas (ETOTRAP). Entomol. Mexicana 2008, 7, 610-624. (In Spanish).

90. Uemura-Lima, D.H.; Ventura, M.U.; Mikami, A.Y.; da Silva, F.C.; Morales, L. Response of coffee berry borer, Hypothenemus hampei (Ferrari) (Coleoptera: Scolytidae) to vertical distributions of methanol: Ethanol traps. Neotrop. Entomol. 2010, 39, 930-933. [CrossRef] [PubMed]

91. Chamorro, T.G.; Cárdenas, R.; Herrera, H.A. Evaluación económica y de la calidad en taza del café proveniente de diferentes sistemas de recolección manual, utilizables como control en cafetales infestados de Hypothenemus hampei. Rev. Cenicafé 1995, 46, 164-175. (In Spanish).

92. Saldarriaga, A.G. Evaluación Prácticas Culturales en el Control de la Broca del café, Hypothenemus hampei (Ferrari 1867) (Coleoptera: Scolytidae). BSc. Thesis, Universidad Nacional de Colombia, Medellín, Colombia, 1994; p. 57. (In Spanish).

93. Peralta, J. Diagnóstico de la Labor de Recolección y Repase Para el Manejo de la Broca del café Hypothenemus hampei (Ferrari) (Coleoptera: Scolytidae) por Agricultores. B.Sc. Thesis, Universidad Nacional de Colombia, Palmira, Colombia, 1995; p. 71. (In Spanish).

94. Díaz, Y.; Marín, H.F. Evaluación de los Frutos de Café Dejados Después de las Recolecciones Durante un Ciclo Productivo del Cultivo en dos Municipios del Departamento de Caldas. BSc. Thesis, Universidad de Caldas. Manizales, Colombia, 1999; p. 96. (In Spanish).

95. Aristizábal, L.F.; Bustillo, A.E.; Jiménez, M.; Trujillo, H.I.V. Encuentro de caficultores experimentadores. Manejo integrado de la broca del café a través de investigación participativa; Convenio Colciencias-FNC-Cenicafé-Fundación Manuel Mejía. Cenicafé: Chinchiná, Colombia, 2004; p. 70. (In Spanish) 
96. Bergamin, J. O "repase" como método de controle da broca do café "Hypothenemus hampei (Ferr., 1867)" (Col. Ipidae). Arq. Inst. Biol. Sao Paulo 1944, 15, 197-208. (In Portuguese).

97. Mesquina, F. de C. A broca do café no Estado do Rio de Janeiro. Biletim Fitossanitarío 1944, 1, $247-253$. (In Portuguese).

98. Villacorta, A. Ocurrencia de Beauveria sp. Infectando a broca do café-Hypothenemus hampei (Ferrari 1867) (Coleoptera: Scolytidae) em lavouras no estado do Paraná. An. Soc. Entomol. Bras. 1984, 13, 177-178. (In Portuguese).

99. Vélez-Arango, P.E.; Benavides-Gómez, M. Registro e identificación de Beauveria bassiana en Hypothenemus hampei en Ancuya, Departamento de Nariño, Colombia. Rev. Cenicafé 1990, 41, 50-57. (In Spanish).

100. Lazo, A.R.R. Susceptibilidad de la Broca del Fruto del Cafeto (Hypothenemus hampei) al Hongo Entomopatógeno Beauveria bassiana, y su Tolerancia a Oxicloruro de Cobre. M.Sc. Thesis, Centro Agronómico Tropical de Investigación y Enseñanza, Turrialba, Costa Rica, 1990; p. 61. (In Spanish).

101. Méndez-López, I. Control Microbiano de la Broca del Fruto del Cafeto Hypothenemus hampei Ferrari (Coleoptera: Scolytidae), en el Soconusco, Chiapas. M.Sc. Thesis, Colegio de Postgrados, Chapingo, México, 1990; p. 135. (In Spanish).

102. Echeverría, B.F. Caracterización Biológica y Molecular de Asilamientos del Hongo Entomopatógeno Beauveria bassiana (Balsamo). Vuillemin. B.Ss. Thesis, Escuela de Biología, Instituto Tecnológico de Costa Rica, Cartago, Costa Rica, 2006; p. 92. (In Spanish).

103. Gallardo-Covas, F.; Hernández, E.; Pagán, J. Presencia natural del hongo Beauveria bassiana (Bals.) Vuill. En la broca del fruto del café Hypothenemus hampei (Ferrari) en Puerto Rico. J. Agric. Univ. 2010, 94, 195-198. (In Spanish).

104. Costa, J.N.M.; da Silva, R.B.; de Araújo Ribeiro, P.; Garcia, A. Ocorrencia de Beauveria bassiana (Bals.) Vuill. sEm broca-do-café (Hypothenemus hampei, Ferrari) no estado de Rondonia, Brasil. Acta Amazon. 2002, 32, 517-519. (In Portuguese). [CrossRef]

105. Monzón, A.J.; Guharay, F.; Klingen, I. Natural occurrence of Beauveria bassiana in Hypothenemus hampei (Coleoptera: Curculionidae) population in unsprayed coffee fields. J. Invertebr. Pathol. 2008, 97, 134-141. [CrossRef] [PubMed]

106. Balakrishnam, M.M.; Sreedharan, K.; Krishnammoorthy Bhat, P. Occurrence of the entomopathogenic fungus Beauveria bassiana on certain coffee pests in India. J. Coffee Res. 1994, 24, 33-35.

107. Mbang, J.A.à.; Mounjouenpou, P.; Mahob, R.J.; Mbarga, A.M.; Mouen Bedimo, J.; Nyasse, S. Evaluaation naturelle de I'impact de Beauveria bassiana: Champignon entomopathogène dans la dynamique de population de Hypothenemus hampei, scolyte de baies des cerises de Coffea canefora. Afr. Crop. Sci. J. 2012, 20, 443-451.

108. Vélez, P.E.; Montoya, E.C. Supervivencia del hongo Beauveria bassiana bajo radiación solar en condiciones de laboratorio y campo. Rev. Cenicafé 1993, 44, 111-122. (In Spanish).

109. Lacayo, L.; Barrios, M.; Jiménez, C.; Sandino, V. El uso de hongos entomopatógenos para el manejo de la broca del café (Hypothenemus hampei) en Nicaragua. Ministerio de Agricultura y Ganadería. Managua, Nicaragua. Available online: http://naples-fl-real-estate.info/Record/434679 (accessed on 3 August 2015). (In Spanish).

110. Posada, F.F.J.; Salazar, E.H.M.; Aristizábal, A.L.F.; Mejía, C.G.; Jiménez, M. Taller con caficultores en el control de Hypothenemus hampei (Ferrari) (Coleoptera: Scolytidae). Rev. Colomb. Entomol. 2003, 29, 63-70. (In Spanish).

111. Vega, F.E.; Meyling, N.V.; Luangsa-ard, J.J.; Blackwll, M. Fungal entomopathogens pp. In Insect Pahology, 2nd ed.; Vega, F.E., Kaya, H.K., Eds.; Academic Press: San Diego, CA, USA, 2012; pp. 170-220.

112. Bustillo, A.E.; Castillo, H.; Villalba, D.; Morales, E.; Vélez, P. Evaluaciones de campo con el hongo Beauveria bassiana para el control de la broca del café, Hypothenemus hampei en Colombia. In Proceedings of the ASIC, 14e. Colloque, San Francisco, CA, USA, 14-19 July 1991; pp. 679-686. (In Spanish).

113. Flórez, E.; Bustillo, A.E.; Montoya, E.C. Evaluación de equipos de aspersión para el control de Hypothenemus hampei con el hongo Beauveria bassiana. Rev. Cenicafé 1997, 48, 92-98.

114. Arcila, A.; Bustillo, A.E. Estudios básicos sobre Beauveria bassiana en cafetales de Colombia. In Proceedings of the Informe anual, Disciplina de Entomología, Cenicafé, Chinchiná, Colombia, 1-5 noviembre 1997; p. 22. (In Spanish). 
115. Benavides, P.; Góngora, C.; Bustillo, A. IPM program to control coffee berry borer Hypothenemus hampei, with emphasis on highly pathogenic mixed strains of Beauveria bassiana, to overcome insecticide resistance in Colombia. In Insecticides-Advances in Integrated Pest Management, 1st ed.; Perveen, F., Ed.; InTech Europe: Rijeka, Croatia, 2012; pp. 512-540.

116. Cruz, L.P.; Gaitan, A.L.; Góngora, C.E. Exploiting the genetic diversity of Beauveria bassiana for improving the biological control of the coffee berry borer through the use of strain mixture. Appl. Microbiol. Biotechnol. 2006, 71, 918-926. [CrossRef] [PubMed]

117. Bustillo, A.E.; Bernal, M.G.; Cháves, B.; Benavides, P. Dynamics of Beauveria bassiana and Metarhizium anisopliae infecting Hypothenemus hampei (Coleoptera: Scolytidae) populations emerging from fallen coffee berries. Fla. Entomol. 1999, 82, 491-498. [CrossRef]

118. Vera, J.T.; Montoya, E.C.; Benavides, P.; Góngora, C.E. Evaluation of Beauveria bassiana (Ascomycota: Hypocreales) as a control of the coffee berry borer Hypothenemus hampei (Coleoptera: Curculionidae: Scolytinae) emerging from fallen, infested coffee on the ground. Biocontrol Sci. Technol. 2011, 21, 1-14. [CrossRef]

119. Aristizábal, L.F. Investigación participativa en el manejo integrado de la broca del café. In Proceedings of the Memorias XXXII Congreso Sociedad Colombiana de Entomología, Ibagué, Colombia, 27-29 July 2005; pp. 65-71. (In Spanish).

120. Posada, F.; Vega, F.E. Inoculation and colonization of coffee seed lings (Coffea arabica L.) with the fungal entomopathogen Beauveria bassiana (Ascomycota: Hypocreales). Mycoscience 2006, 47, 284-289. [CrossRef]

121. Posada, F.; Aime, M.C.; Peterson, S.W.; Rehner, S.A.; Vega, F.E. Inoculation of coffee plants with the fungal entomopathogen Beauveria bassiana (Ascomycota: Hypocreales). Mycol. Res. 2007, 111, 748-757. [CrossRef] [PubMed]

122. Vega, F.E.; Posada, F.; Aime, M.C.; Peterson, S.W.; Rehner, S. Fungal endophytes in green coffee seedes. Mycosystema 2008, 27, 75-84.

123. Hollingsworth, R.G.; Daniel, K.; Inouye, U.S. Pacific Basin Agricultural Research Center, USDA/ARS, Hilo, HI, USA. Personal Communication, 2016.

124. Wraight, S.; Keith, L. Efficacy of spray applications of Beauveria bassiana strain GHA (BotaniGard@) against coffee berry borer, Hypothenemus hampei, on Hawaii island. In Proceedings of the 63rd Annual Meeting of the Entomological Society of America ESA, Minneapolis, MN, USA, 15-18 November 2015.

125. Castro, L.; Benavides, M.P.; Bustillo, P.A.E. Dispersión y mortalidad de Hypothenemus hampei, durante la recolección y benéfico del café. Manejo Integrado de Plagas (Costa Rica) 1998, 50, 19-28. (In Spanish).

126. Aristizábal, L.F.; Salazar, H.M.; Mejía, C.G. Evaluación del manejo de la broca del café en las tolvas de recibo y en las fosas para la pulpa, mediante investigación participativa. Avances Técnicos Cenicafé 2002, 297, 1-8. (In Spanish).

127. Hampel, A. A Prorops nasuta Waterston no Brasil. Arquivos Instit. Biol. 1934, 5, 197-212.

128. Abraham, Y.J.; Moore, D.; Godwin, G. Rearing and aspects of biology of Cephalonomia stephanoderis and Prorops nasuta (Hymenoptera: Bethylidae) parasitoids of the coffee berry borer, Hypothenemus hampei (Coleoptera: Scolytidae). Bull. Entomol. Res. 1990, 80, 121-128. [CrossRef]

129. Barrera, J.F.; Infante, F.; Castillo, A.; De la Rosa, W.; Gómez, J. Cría y manejo de Cephalonomia stephanoderis y Prorops nasuta parasitoides de la broca del café. In Proceedings of the Seminario sobre la Broca del Cafeto, Miscelánea No. 18, Medellín, Colombia, Socolen, 21 de mayo de 1990; pp. 76-86. (In Spanish).

130. Benavides, M.; Portilla, M. Uso del café pergamino para la cría de la broca del café, Hypothenemus hampei y de su parasitoide Cephalonomia stephanoderis Betrem en Colombia. In Proceedings of the Seminario sobre la Broca del Cafeto, Miscelánea No. 18, Medellín, Colombia, Socolen, 21 de mayo de 1990; pp. 87-90. (In Spanish).

131. Orozco, J.; Aristizábal, L.F. Parasitoides de origen africano para el control de la broca del café. Avances Técnicos Cenicafé 1996, 223, 1-8. (In Spanish).

132. Yokoyama, M.; Nakano, O.; Rigitano, R.L.; Nakayama, L. Situatçion actual de vespa de Uganda, Prorops nauta Waterston, 1923 (Hymenoptea: Bethylidae) no Brazil. Cientifica 1977, 5, 394. (In Portuguese).

133. Cisneros, P.; Tandazo, A. Evidencias sobre el establecimiento del parasitoide Prorops nasuta W. en el suroriente de Ecuador. In Proceedings of the Seminario sobre la Broca del Cafeto, Miscelánea No. 18, Medellín, Colombia, Socolen, 21 de mayo de 1990; pp. 50-57. (In Spanish). 
134. Campos, A.O.G. Manejo de la broca del café en una finca de producción comercial en Guatemala. In Proceedings of the Simposio sobre Situación Actual y Perspectivas de la Investigación y Manejo de la Broca del Café en Costa Rica, Sociedad Mexicana de Entomología y el Colegio de la Frontera Sur, Tapachula, Chiapas, México, 2005; pp. 38-45. (In Spanish).

135. Infante, F.; Mumford, J.; Méndez, I. Non-recovery of Prorops nasuta (Hymenoptera: Bethylidae), an imported parasitoid of the coffee berry borer (Coleoptera: Scolytidae) in Mexico. Southw. Entomol. 2001, 26, 159-163.

136. Barrera, J.F. Investigaciones sobre la broca del café en México: Logros, retos y perspectivas. In Proceedings of the Simposio sobre Situación Actual y Perspectivas de la Investigación y Manejo de la Broca del Café en Costa Rica. Sociedad Mexicana de Entomología y el Colegio de la Frontera Sur, Tapachula, Chiapas, México, 2005; pp. 1-13. (In Spanish).

137. Quintero, C.; Bustillo, A.E.; Benavides, P.; Cháves, B. Evidencias del establecimiento de Cephalonomia stephanoderis y Prorops nasuta (Hymenoptera: Bethylidae) en cafetales del departamento de Nariño, Colombia. Rev. Colomb. Entomol. 1998, 24, 141-147. (In Spanish).

138. Maldonado, C.E.; Benavides, P. Evaluación del establecimiento de Cephalonomia stephanoderis y Prorops nasuta, controladores de Hypothenemus hampei, en Colombia. Rev. Cenicafé 2007, 59, 333-339. (In Spanish).

139. Aristizábal, L.F.; Salazar, H.M.; Mejía, C.G.; Jiménez, M.; Bustillo, A.E.; Arthurs, S.P. Establishment of exotic parasitoids of the coffee berry borer Hypothenemus hampei (Coleoptera: Curculionidae: Scolytinae) in Colombia through farmer participatory research. Int. J. Trop. Insect Sci. 2012, 1, 24-31. [CrossRef]

140. Gómez, J.; Santos, A.; Valle, J.; Montoya, P.J. Determinación del establecimiento de parasitoides de la broca del café Hypothenemus hampei (Coleoptera: Curculionidae: Scolytinae) en cafetales del Soconusco, Chiapas, México. Entomotrópica 2010, 25, 25-36. (In Spanish).

141. Delgado, D.; Sotomayor, I. Algunos resultados sobre la cría, adaptación y colonización de los entomógenos Prorops nasuta Waters. y Cephalonomia stephanoderis Betrem, en la regulación de poblaciones de H. hampei en el Ecuador. In Proceedings of the Seminario sobre la Broca del Cafeto, Miscelánea No. 18, Medellín, Colombia, Socolen, 21 de mayo de 1990; pp. 58-95. (In Spanish).

142. Benavides, P.; Bustillo, A.E.; Montoya, E.C. Avances sobre el uso del parasitoide Cephalonomia stephanoderis para el control de la broca del café, Hypothenemus hampei. Rev. Colomb. Entomol. 1994, 20, 247-253. (In Spanish).

143. Dufour, B.; Barrera, J.F.; Decazy, B. La broca de los frutos del cafeto: la lucha biológica como solución? In Desafíos de la caficultura Centroamericana; Bertrand, B., Rapidel, B., Eds.; IICA PROMECAFE: San José, Costa Rica, 1999; pp. 293-325. (In Spanish)

144. Aristizábal, L.F.; Baker, P.S.; Orozco, J.; Cháves, B. Parasitismo de Cephalonomia stephanoderis Betrem sobre una población de Hypothenemus hampei (Ferrari) con niveles bajos de infestación en campo. Rev. Colomb. Entomol. 1997, 23, 157-164. (In Spanish).

145. Aristizábal, L.F.; Bustillo, A.E.; Orozco, J.; Cháves, B. Efecto del parasitoide Cephalonomia stephanoderis (Hymenoptera: Bethylidae) sobre las poblaciones de Hypothenemus hampei (Coleoptera: Scolytidae) durante y después de la cosecha. Rev. Colomb. Entomol. 1998, 24, 149-155. (In Spanish).

146. Salazar, H.M.; Baker, P.S. Impacto de liberaciones de Cephalonomia stephanoderis sobre poblaciones de Hypothenemus hampei. Rev. Cenicafé 2002, 53, 306-316. (In Spanish).

147. Ferreira, A.J.; Bueno, V.H.P. Ocurrência da vespa de Uganda, Prorops nasuta Waterston, 1923 (Hymenoptera: Bethylidae) na região de Lavras-MG. Ciência e Practica 1995, 19, 226-227. (In Portuguese).

148. Aristizábal, L.F.; Jiménez, M.; Bustillo, A.E.; Arthurs, S.P. Introduction of parasitoids of Hypothenemus hampei (Coleoptera: Curculionidae: Scolytinae) on small coffee plantations in Colombia through farmer participatory methods development. Fla. Entomol. 2011, 94, 690-693. [CrossRef]

149. Bacca, R.T. Efecto del Parasitoide Prorops nasuta Waterston (Hymenoptera: Bethylidae) Sobre Poblaciones de Broca del Café Hypothenemus hampei (Ferrari) (Coleoptera: Scolytidae). M.Sc. Thesis, Universidad Nacional de Colombia, Facultad de Agronomía, Santafé de Bogotá, 1999; p. 186. (In Spanish).

150. Jaramillo, J.; Chabi-Olaye, A.; Borgemeister, C.; Kamonjo, C.; Poehling, H.M.; Vega, F.E. Where to simple? Ecological implications of sampling strata in determining abundance and impact of natural enemies of the coffee berry borer, Hypothenemus hampei. Biol. Contr. 2009, 49, 245-253. [CrossRef]

151. Jervis, M.A.; Kidd, N.A.C. Host feeding strategies in hymenopteran parasitoids. Biol. Rev. 1986, 61, $395-434$. [CrossRef] 
152. Aristizábal, L.F.; Bustillo, A.E.; Baker, P.S.; Orozco, J.; Cháves, B. Efecto depredador del parasitoide Cephalonomia stephanoderis (Hymenoptera: Bethylidae) sobre los estados inmaduros de Hypothenemus hampei (Coleoptera: Scolytidae) en condiciones de campo. Rev. Colomb. Entomol. 1998, 24, 35-42. (In Spanish).

153. Orozco, H.J. Guía para la producción del parasitoide Phymastichus coffea para el control de la broca del café, CFC-Cenicafé-CABI-Commodities -ICO, Colombia, 2002, 19. (In Spanish).

154. Vergara, O.J.D. Biología y Comportamiento de Phymastichus coffea LaSalle (Hymenoptera: Eulophidae), Parasitoide de la Broca del Café en Condiciones de Campo. B.Sc. Thesis, Universidad Nacional de Colombia, Medellín, Colombia, 1998; p. 67. (In Spanish).

155. Echeverry, O.A. Determinación del Impacto de Phymastichus coffea La Salle (Hymenoptera: Eulophidae) Sobre Poblaciones de Broca del Café Hypothenemus hampei (Ferrari) (Coleoptera: Scolytidae), en la zona Cafetera. B.Sc. Thesis, Universidad Nacional de Colombia, Palmira, Colombia, 1999; p. 113. (In Spanish).

156. Aristizábal, L.F.; Salazar, H.M.; Mejía, C.G.; Bustillo, A.E. Introducción y evaluación de Phymastichus coffea (Hymenoptera: Eulophidae) en fincas de pequeños caficultores a través de investigación participativa. Rev. Colomb. Entomol. 2004, 30, 219-224. (In Spanish).

157. Galindo, V.H.; Infante, F.; Castillo, A.; Barrera, J.F.; Pinson, E.; González, G.; Espinoza, J.C. Establecimiento preliminar del parasitoide Phymastichus coffea (Hymenoptera: Eulophidae) en Chiapa, México. In Proceedings of the Memorias del XXY Congreso Nacional de Control Biológico, Hermosillo, México, 11- 15 de noviembre de 2002; pp. 44-46. (In Spanish).

158. Vélez, M. Hormigas y su papel en el control biológico de la broca del café. In Proceedings of the Memorias Curso Internacional Teórico-Práctico. Sección II, Parasitoides y otros enemigos de la broca del café, Cenicafé, Chinchiná, marzo 18 al 22 del 2002; pp. 15-23. (In Spanish).

159. Vázquez-Moreno, L.L.; Matienzo-Brito, Y.; Alfonso-Simonetti, J.; Moreno-Rodríguez, D.; Alvarez-Núñez, A. Diversidad de especies de hormigas (Hymenoptera: Formicidae) en cafetales afectados por Hypothenemus hampei Ferrari (Coleoptera: Curculionidae: Scolytinae). Fitosanidad 2009, 13, 163-168. (In Spanish).

160. Chapman, E.G.; Jaramillo, J.; Vega, F.E.; Harwood, J.D. Biological control of coffee berry borer: The role of the DNA-based gut-content analysis in assessment of predation. In Proceedings of the 3rd International Symposium on biological Control of Arthropods, Christchurch, New Zealand, 8-13 February 2009; Mason, P.G., Gillespie, D.R., Vicent, C., Eds.; pp. 475-484.

161. Jaramillo, J.; Chapman, E.G.; Vega, F.E.; Harwood, J.D. Molecular diagnosis of a previously unreported predator-prey association in coffee: Karnyothrips flavipes Jones (Thysanoptera: Phlaeothripidae) predation on the coffee berry borer. Naturwissenschaften 2010, 97, 291-298. [CrossRef] [PubMed]

162. Bustillo, A.E.; Cárdenas, R.; Posada, F.J. Natural enemies and competitors of Hypothenemus hampei (Ferrari) (Coleoptera: Scolytidae) in Colombia. Neotropical Entomol. 2002, 31, 635-639. [CrossRef]

163. Rojas, H.W.; Morales, J.; Delgado, C.; Marín, R.; Torres-Murillo, L.C. Identification of natural enemies of the coffee berry borer (Hypothenemus hampei) in Costa Rica. In Proceedings of the 24th International Scientific Colloquium on Coffee, Association Scientifique Internationale du Café (ASIC), San José, Costa Rica, 12-16 November 2012; pp. 1266-1269.

164. Follet, P.A.; Kawabata, A.; Nelson, R.; Asmus, G.; Burt, J.; Goshke, K. Predaceous flat bark beetles munch on coffee berry borer in Hawaii coffee. In Proceedings of the 63rd Annual Meeting of the Entomological Society of America ESA, Minneapolis, MN, USA, 15-18 November 2015.

165. Follet, P.A.; Daniel, K.; Inouye, U.S. Pacific Basin Agricultural Research Center, USDA/ARS, Hilo, HI, USA. Personal Communication, 2015.

166. Molina, J.P.; López, J.C. Desplazamiento y parasitismo de entomonematodos hacia frutos infestados con la broca del café, Hypothenemus hampei (Coleoptera: Scolytidae). Rev. Colomb. Entomol. 2002, 28, 145-151. (In Spanish).

167. Lara, J.C.; López, J.C.; Bustillo, A.E. Efecto de entomonematodos sobre poblaciones de la broca del café, Hypothenemus hampei (Coleoptera: Scolytidae), en frutos en el suelo. Rev. Colomb. Entomol. 2004, 30, 179-185. (In Spanish).

168. Manton, J.L.; Hollingsworth, R.G.; Cabos, R.Y.M. Potential of Steinernema carpocapsae (Rhabditida: Steinernematidae) against Hypothenemus hampei (Coleoptera: Curculionidae) in Hawai'i. Fla Entomol. 2012, 95, 1194-1197. [CrossRef] 
169. Aristizábal, L.F.; Salazar, H.M.; Mejía, C.G. Evaluación de dos componentes del manejo de la broca en la renovación de cafetales, mediante investigación participativa. Avances Técnicos Cenicafé 2002, 295, 1-8. (In Spanish).

170. Bittenbender, H.C.; Smith, V.E. Growing coffee in Hawaii; College of Tropical Agriculture and Human Resources, University of Hawai'i: Honolulu, USA, 2008; pp. 1-40.

171. Bentley, W.; Baker, S.P.; Aristizábal, L.F.; Campos, O.; Chilan, W.; Garcia, A.; Muñoz, R.; Jarquín, A.; Larco, A.; Mejia, C.G.; et al. Manual for collaborative research with smallholder coffee farmers. "What we learned from the CFC-IPM Coffee Project". Available online: http://agroinsight.com/downloads/ books/Coffee-manual-English.pdf (accessed on 3 July 2015).

172. Bentley, J.W. Impact of IPM extension for smallholders farmers in the Tropics. In Integrated Pest Management: Dissemination and Impact; Peshin, R., Dhawan, A.K., Eds.; Springer Science-Business Media, 2009; pp. 333-345.

173. Duque, H.; Cháves, B. Estudio Sobre Adopción del Manejo Integrado de la Broca del Café; Cenicafé: Chinchiná, Colombia, 2000; p. 90.

174. Aristizábal, L.F.; Vélez, J.C.; León, C.A. Diagnóstico del manejo de la broca del café, Hypothenemus hampei (Ferrari) (Coleoptera: Curculionidae) con caficultores de Caldas. Rev. Colomb. Entomol. 2006, 32, 117-124.

(C) 2016 by the authors; licensee MDPI, Basel, Switzerland. This article is an open access article distributed under the terms and conditions of the Creative Commons by Attribution (CC-BY) license (http://creativecommons.org/licenses/by/4.0/). 